Janusz Szymański

Uniwersytet w Białymstoku

e-mail: janusz_szymanski@interia.eu

\title{
Instytucja ratyfikacji umów międzynarodowych i konsekwencje zmiany jej charakteru prawnego z perspektywy historycznej
}

\begin{abstract}
SUMMARY
The Ratification of International Treaties and the Consequences of the Change of its Legal Character from the Historical Perspective
\end{abstract}

In this article, the meaning and nature of ratification is discussed. It is shown that in early practice and doctrine, ratification was a confirmation that what had been signed had been duly and properly signed - an acknowledgment by a principal of the act of his agent. No doubt, this theory was not a strict acceptance of the doctrine of private law agency, even at a time when private law analogies were more freely accepted than they are today. For ratification of an act of an agent concluded within the limits of his authority is not strictly necessary in private law. But the difference is purely formal. In both cases - treaties and contracts made by agents - the signed document created obligations. In international law the document was not perfectly binding until a ratification was issued.

It is, at any rate, clear that the private law analogy was valid in the seventeenth, and the greater part of the eighteenth, centuries to this extent: the duty to ratify - i.e. to acknowledge publicly the binding force of a signed treaty - was held not to apply when the agent had exceeded his instructions. This was the only generally recognized ground for refusing a ratification.

The French and American Revolutions changed all this. They attempted to banish from public law the notion of absolute power. Indeed, for a short interval, as has been shown, the treatymaking power was vested in a national assembly - in France, the National Convention, in the United States, in Congress. But this was found impracticable, and in the United States the Senate reserved only the power to sanction and participate in the final act of ratification. When this deliberative element was introduced into the process of ratification, it became apparent that ratification could no longer be regarded as obligatory.

An account of ratification in theory and in practice is incomplete without a study of the formal clauses in treaties with regard to the date of their coming into force. It is clear that, in many 
cases, ratification is dispensed with, either for reasons of expedition, or because ratification does not require any deliberation according to the constitutional practice of the States concerned. On the other hand, the development of the multipartite treaty caused signature or accession to supplant ratification, in the increasingly common case of States becoming parties to a treaty to which they are not original signatories.

The very large number of constitutional texts prescribing a specific procedure for the conclusion of treaties, the changed character of ratification, and the existence in formal documents, and in treaties themselves, of clear stipulations as to satisfaction of constitutional requirements, it is impossible to ignore the relevance of such provisions in international law.

Key words: treaty, ratification, signature, accession, Full Power

\section{Uwagi ogólne}

Ratyfikacja umów międzynarodowych stanowi z pewnością najbardziej solenny, najbardziej uroczysty sposób wyrażania przez państwo zgody na zaciągnięcie zobowiązań umownych ${ }^{1}$.

Konieczność zachowania instytucji ratyfikacji uzasadnia się dzisiaj nie tylko względami prawnymi, ale i politycznymi.

Ratyfikacja umów międzynarodowych daje przede wszystkim możliwość:

- dokonania w spokojnej atmosferze ponownej i gruntownej analizy treści podpisanej już umowy,

- kontroli czynności pełnomocników,

- kontroli parlamentarnej działań rządu w dziedzinie obrotu traktatowego i zapewnia wyższy poziom zarówno ochrony, jak i implementacji umów międzynarodowych w porządku prawnym państwa,

- zapoznania opinii publicznej z treścią postanowień umowy.

Ratyfikacja umów międzynarodowych jest aktem o długiej już tradycji, a jej historia sięga swymi początkami do okresu średniowiecza.

Należy zauważyć iż:

- ratyfikacja umów międzynarodowych należy do praw każdego państwa, nie zaś do jego obowiązków²,

1 Por. M. Frankowska, Umowa międzynarodowa. Wprowadzenie do prawa traktatów, Warszawa 1977, s. 44.

2 Państwa nie mają obowiązku ratyfikowania podpisanej umowy przez pełnomocnika umowy i zachowują pełną swobodę decyzji w tej sprawie, bowiem nie ma żadnej normy prawnomiędzynarodowej, z której wynikałby taki obowiązek, por. J. L. Brierly, Law of Nation, Oxford 1936, s. 196 - „There is no legal, nor even a moral, duty on the State to ratify a treaty signed by its own plenopotentiaries; it can only be said that refusal is a serious step which ought not to be taken lightly". Również konwencja wiedeńska o prawie traktatów z 1969 r. nie zawiera takiego obowiązku. 
- wszelkie zmiany formy ratyfikacji nie doprowadziły nigdy do wyeliminowania innych niż ratyfikacja sposobów wyrażania przez państwo zgody na związanie się umową międzynarodową (nie było bowiem takiego okresu w historii stosunków traktatowych, w którym państwa zawierałyby umowy wyłącznie w drodze tej procedury (przez ratyfikację)

- rygorystyczne ramy ratyfikacji doprowadziły przede wszystkim do omijania tej instytucji i rozwoju umów w formie uproszczonej, a w Stanach Zjednoczonych do powstania nowej kategorii umów międzynarodowych, tj. porozumień wykonawczych prezydenta (executing agreements) ${ }^{4}$, a więc grupy umów stanowiących dogodny instrument władzy wykonawczej,

- ratyfikacja jest zarówno gwarantem bezpieczeństwa obrotu w sferze prawnomiędzynarodowej, jak i gwarantem realizacji zasady demokratycznego państwa prawnego (rule of law).

Praktyka na ogół potwierdza, iż ratyfikacji nie wymagają następujące kategorie umów międzynarodowych ${ }^{5}$ :

- deklaracje o treści politycznej przyjmowane na spotkaniach mężów stanu, np. Karta Atlantycka przyjęta przez Prezydenta Stanów Zjednoczonych i premiera Wielkiej Brytanii na pancerniku Prince of Wales 4 sierpnia $1941 \mathrm{r}^{6}$,

- umowy w formie wymiany not,

- umowy resortowe zawierane przez ministrów i kierowników urzędów centralnych w zakresie ich działania,

- umowy wojskowe zawierane zarówno w czasie pokoju, jak i wojny (np. kartele, umowy rozejmowe, konwencje wojskowe) ${ }^{7}$.

Trudno zaliczać do tych kategorii umów - umowę jałtańską czy umowę poczdamską, które weszły w życie bez ratyfikacji ${ }^{8}$. Również porozumienie o za-

3 Por. M. Frankowska, O domniemaniu wymagania ratyfikacji umów międzynarodowych, „Państwo i Prawo" 1969, nr 3, s. 540.

4 Por. W. M. McClure, International Executive Agreements, New York 1941, s. 38 i nast. oraz F. O. Wilcox, The Ratification of International Conventions, London 1935, s. 229 i nast.

5 Zob. J. Makowski, O zawieraniu umów międzynarodowych, Warszawa 1937, s. 98 oraz R. Bierzanek, J. Jakubowski, J. Symonides, Prawo międzynarodowe i stosunki międzynarodowe, Warszawa 1980, s. 99. Jednak pogląd ten nie wydaje się trafny.

6 Na przykład Protokół Konsultancyjny włosko-austriacko-węgierski, podpisany w Rzymie 17 marca 1943 r. przez Mussoliniego, Dolifusa i Gömbösa, nie zawierał wzmianki o ratyfikacji, ani o wejściu w życie; powszechnie uważa się, iż uprawomocnił się w chwili podpisania. Tak samo Układ Monachijski z 29 października 1938 r., podpisany przez Hitlera, nie był ratyfikowany.

7 Na przykład porozumienia dotyczące zawieszenia broni dla ewakuacji rannych i zabitych po kapitulacji Niemiec, podpisany w dniu 8 maja $1945 \mathrm{r}$.

8 Zdaniem J. Makowskiego, brak wzmianki o ratyfikacji w umowach zawieranych bezpośrednio po drugiej wojnie światowej był skutkiem powszechnego obniżenia się poziomu dyplomacji europejskiej, zob. J. Makowski, Podręcznik Prawa Międzynarodowego, Warszawa 1948, s. 459 oraz idem, Charakter prawny umów zawartych podczas drugiej wojny światowej, „Państwo i Prawo” 1948, nr 5/6, s. 9-24. 
przestaniu wojny i przywróceniu pokoju w Wietnamie z 27 stycznia 1973 r. nie wymagało ratyfikacji.

Ratyfikacja umów międzynarodowych to ostateczne jej zatwierdzenie przez najwyższy organ władzy państwowej (zazwyczaj przez głowę państwa) ${ }^{9}$.

Ratyfikacja oznacza tak zwany akt międzynarodowy, przez który państwo na płaszczyźnie międzynarodowej wyraża swą zgodę na związanie się traktatem ${ }^{10}$.

Jest charakterystyczne, że ratyfikacja umów międzynarodowych przejawia się w dwóch odrębnych aktach:

- międzynarodowym (dokumencie ratyfikacyjnym),

- wewnętrznym (wewnątrzpaństwowym akcie normatywnym) ${ }^{11}$,

które obrazują wyraźnie dwie funkcje ratyfikacji (jej dwoisty, dualistyczny charakter):

- międzynarodową,

- wewnętrzną.

Ratyfikacja umowy międzynarodowej nie jest obowiązkową procedurą (aktem) zawarcia umowy, tym niemniej w tych wypadkach, kiedy umowa międzynarodowa wymaga ratyfikacji (bezpośrednio przewiduje ten sposób jej uprawomocnienia), stanowi ona konieczny i niezbędny etap (do nadania jej skuteczności) w procesie jej zawarcia. Z uwagi na fakt, iż ratyfikacji dokonują najwyższe organy państwa, jest ona najbardziej autorytatywną formą wyrażania przez państwo zgody na związanie się umową międzynarodową, a ponadto stanowi formę nobilitacji samej umowy.

Zatem można zauważyć, iż ratyfikacja umów międzynarodowych jest szczególną formą wyrażania przez państwo zgody na związanie się umową w sposób ostateczny, uzewnętrznioną na płaszczyźnie międzynarodowej w postaci wymiany lub złożenia dokumentu ratyfikacyjnego (lub współcześnie - notyfikacją dokonaniu ratyfikacji). Jest ona jednym ze sposobów zawarcia umowy międzynarodowej w trybie złożonym (etapem definitywnym), stanowiącym istotne zabezpieczenie interesów suwerennego państwa. $\mathrm{Z}$ tego względu należy stwierdzić, iż ratyfikacja umów międzynarodowych jest zarówno instytucją prawa międzynarodowego, jak i prawa wewnętrznego. Jest więc instytucją o dwojakim charakterze: prawnomiędzynarodowym i prawnowewnętrznym, gdyż związanie się przez państwo umową międzynarodową uzależnione jest od realizacji czynności zarówno wewnętrznych, jak i prawnomiędzynarodowych. Same czynności wewnętrzne (wewnątrzpaństwowy akt zatwierdzenia umowy, który konstytucje $\mathrm{z}$ reguły określają jako ratyfikację) nie stanowią podstawy do związania się przez państwo umową międzynarodową i wymagają uzewnętrz-

9 Por. P. Freymond, La Ratification des Traités et le Problème Des Rapports Entre Le Droit International Et Le Droit Interne, Paris - Lausanne 1947, s. 45.

10 Ibidem; por. również: O. E. Polenc, Ratyfikacija mieżdunarodnych dogoworow, Moskwa 1950, s. 7.

11 Zob. A. N. Tałałajew, Prawo mieżdunarodnych dogoworow, Moskwa 1980, s. 148. 
nienia aktu ratyfikacji. Zatem wymiana dokumentów ratyfikacyjnych przy umowach dwustronnych i złożenia dokumentu ratyfikacyjnego przy umowach wielostronnych jest momentem decydującym o związaniu się przez państwo daną umową międzynarodową.

Artykuł 14 konwencji wiedeńskiej o prawie traktatów wyraźnie określił, kiedy umowa międzynarodowa wymaga ratyfikacji. Zgodnie z tym artykułem: „Zgoda państwa na związanie się traktatem jest wyrażona przez ratyfikację wówczas, gdy:

a) traktat postanawia, że zgoda może być wyrażona w drodze ratyfikacji,

b) w inny sposób stwierdzono, że państwa negocjujące uzgodniły, iż ratyfikacja winna być wymagana,

c) przedstawiciel państwa podpisał traktat $\mathrm{z}$ zastrzeżeniem ratyfikacji,

d) zamiar państwa podpisania traktatu z zastrzeżeniem ratyfikacji wynika z pełnomocnictwa jego przedstawiciela lub został wyrażony w trakcie negocjacji”.

Taka redakcja artykułu 14 konwencji wiedeńskiej w konsekwencji wyeliminowała sytuacje niejasne i odrzuciła domniemanie wymagania ratyfikacji, które funkcjonowało od lat ${ }^{12}$, w przypadku kiedy $\mathrm{w}$ umowie międzynarodowej brak było odpowiedniego postanowienia przewidującego jej ratyfikację (np. wskutek przeoczenia). Ratyfikacja umów międzynarodowych ma niewątpliwie swe korzenie $\mathrm{w}$ prawie wewnętrznym ${ }^{13}$. Warto podkreślić, iż z punktu widzenia prawa międzynarodowego wybór formy, w jakiej państwo wiąże się w sposób ostateczny daną umową, jest sprawą obojętną. Ważne jest tylko, by zamiar jej zawarcia był wyrażony w sposób jasny ${ }^{14}$. O tym, jaki tryb zawarcia wybrały umawiające się państwa, dowiadujemy się najczęściej z tekstu samej umowy (umowa zawiera np. klauzulę ratyfikacyjną).

Odmowa ratyfikacji umowy międzynarodowej nie jest uważana za naruszenie norm prawa międzynarodowego. Jednak nieuzasadnione przypadki odmowy ratyfikacji, występujące często w praktyce niektórych państw (np. USA, Rosji), wyraźnie nie sprzyjają rozwojowi współpracy międzynarodowej.

Ratyfikacja umów międzynarodowych ma ogromne znaczenie polityczne, stanowi jeden z głównych instrumentów realizacji założeń polityki zagranicznej

12 Na przykład w ustawie, dekrecie, uchwale.

13 Doktrynę „domniemania wymogu ratyfikacji” sformułował w 1737 r. Korneliusz van Bynkershoek (Quaestionum Juris Publici Libri Duo, Leyda 1737, ks. II, rozdz. VII, s. 228-235). Według tej teorii ratyfikacja jest zawsze niezbędna do ważności traktatu, nawet w sytuacji, gdyby warunek ratyfikacji nigdzie nie był wymieniony. Odrzuciła ona całkowicie, przeniesioną przez Hugo Grocjusza do prawa międzynarodowego, prawno-cywilną koncepcję mandatu, zgodnie z którą umowa podpisana przez delegatów w granicach ich jawnych pełnomocnictw, stawała się prawomocna już w chwili podpisania, a ratyfikacja nie miała znaczenia konstytutywnego. W rezultacie potwierdzała akt prawny już istniejący i obowiązujący dla stron. Warto podkreślić ponadto, iż teoria Bynkershoeka zyskała szczególnie na sile w epoce państwa konstytucyjnego (po rewolucji francuskiej).

14 Zob. J. M. Jones, Full powers and ratification, Cambridge 1946, s. 66. 
państwa w sferze stosunków traktatowych. Za ciekawą ilustrację tej tezy może służyć przykład ostrej walki w RFN wokół ratyfikacji układów o podstawach normalizacji stosunków z 1970 r., które Republika Federalna Niemiec zawarła z ZSRR i PRL, czy w USA w sprawie ratyfikacji układu z ZSRR z 1979 r. SALL-II. Od odmowy ratyfikacji należy zdecydowanie odróżnić ratyfikację warunkową.

\section{Instytucja ratyfikacji i jej rola w ujęciu historycznym}

Ratyfikacja w procesie zawierania umów międzynarodowych w poszczególnych okresach rozwoju prawa traktatów miała różne znaczenie prawne. Wiązało się to w sposób oczywisty z faktem, iż instytucja ta ulegała przeobrażeniom, głównie za sprawą istotnych przemian, które zachodziły przede wszystkim w prawie wewnętrznym (konstytucyjnym) zasadniczych partnerów stosunków międzynarodowych. Wypada podkreślić, iż na skutek ewolucji prawa konstytucyjnego, które wpływając na zmianę charakteru prawnego instytucji ratyfikacji - zmieniało w konsekwencji w sposób zasadniczy istotę odrębności w łonie samych umów. Dopiero z czasem zmiany te wskazały na potrzebę dokonania rozróżnienia nie tylko między traktatem a umową uproszczoną, ale i pomiędzy innymi niż ratyfikacja sposobami zawarcia umowy międzynarodowej.

Jest charakterystyczne w okresie absolutyzmu, iż forma stosunków prawnotraktatowych wynikała bezpośrednio z faktu, że za podmioty prawa międzynarodowego uznawani byli panujący. Oni to właśnie posiadali ius contrahendi, a zaciąganie zobowiązań miało $\mathrm{w}$ swej istocie wszystkie cechy prywatnoprawne. Panujący - jako kontrahenci zawieranych umów niejednokrotnie sami brali udział w zawarciu umowy, podpisując odpowiednie dokumenty ze skutkiem wiążącym. Jednak zazwyczaj zawierali oni umowy za pośrednictwem pełnomocników. Pełnomocnicy podpisywali jedynie umowy, a władca je tylko potwierdzał - ratyfikował.

W okresie absolutyzmu stosunek między monarchą a jego wysłannikiem traktowany był tak - jak prywatnoprawny stosunek mandatu. Taką ocenę w tym czasie prezentowali m.in.: A. Gentilis, H. Grocjusz, M. de Wicquefort, Ch. Wolff oraz E. de Vattel ${ }^{15}$. I tak M. de Wicquefort stwierdzał wyraźnie: „Tak jak prawo cywilne zobowiązuje jednostkę do przyjęcia tego, co mandatariusz

15 Por. A. Gentilis, De iure belli libri tres (1598), wyd. Classics of International Law, Oxford - London 1933, ks. III, rozdz. 14, s. 594-595; H. Grocjusz, Trzy ksiegi o prawie wojny i pokoju (1625), przekł. R. Bierzanek, t. 1, Warszawa 1958, s. 446; M. de Wicquefort, L'Ambassadeur et ses fontions, t. 2, Haga 1724, s. 358; Ch. Wolf, Ius gentium methodo scientifica pertractatum (1764), wyd. Classics of International Law, Oxford - London 1943, s. 136, 372 i nast.; E. de Vattel, Prawo narodów, przekł. B. Winiarski wg wyd. z 1758, t. 1, Warszawa 1985, s. 429. 
uczynił na podstawie swego mandatu, tak prawo narodów zobowiązuje władcę do ratyfikowania tego, co zdziałał jego minister w oparciu o pełnomocnictwo"16.

Podobnie pisał również de Vattel: „Tu można zastosować wszystkie reguły prawa naturalnego co do spraw załatwianych przez zastępców. Prawa pełnomocnika określa dane mu pełnomocnictwo. Od tego nie powinien odstępować, ale wszystko, do czego się zobowiązuje stosownie do brzmienia instrukcji, w granicach swego pełnomocnictwa, wiąże jego mocodawcę"17.

Jest oczywiste, iż takie ujęcie pociągało za sobą istotne konsekwencje, co do skutków prawnych działań pełnomocnika. Otóż zgodnie z rzymską zasadą qui facit per alium, facit per se, zobowiązywał pełnomocnik swego władcę w sposób ostateczny, z tym wszakże zastrzeżeniem, że działał zgodnie z zakresem przyznanego mu pełnomocnictwa ${ }^{18}$. Tym samym ratyfikując podpisaną umowę monarcha potwierdzał tylko pełnomocnictwa wystawione uprzednio dla swojego przedstawiciela.

Natomiast sam akt ratyfikacji posiadał w tym czasie - charakter w swej istocie jedynie formalny ${ }^{19}$. Praktyka potwierdza, iż ratyfikacja w sposób naturalny następowała po podpisaniu umowy. Władca miał w istocie obowiązek potwierdzania wszystkiego na co zgodził się przedstawiciel, jeżeli tylko ten ostatni nie przekroczył przyznanych mu uprawnień ${ }^{20}$.

Jednak dopiero później z odmienną koncepcją charakteru prawnego ratyfikacji, jak również istoty stosunku między panującym a jego pełnomocnikiem wystąpił C. van Bynkershoek ${ }^{21}$. Jednak pozostała ona wówczas bez większego znaczenia $^{22}$. Zdaniem Bynkershoeka „o definitywnym zawarciu umowy decy-

16 Por. M. de Wicquefort, op. cit., s. 385.

17 Por. E. de Vattel, op. cit., s. 429.

18 Por. J. M. Jones, op. cit., s. 67-68.

19 Bardzo trafnie określił go de Wicquefort nazywając go „aktem prawnym szczególnym” w przeciwieństwie do traktatu - „aktu wspólnego i publicznego”, zob. M. de Wicquefort, op. cit., s. 376.

20 Por. M. de Wicquefort op. cit., s. 376 i 377 . Autor ten pisał: „Jeśli ambasador nie przekroczył swego pełnomocnictwa [...] władca jest zobowiązany do przyjęcia i ratyfikowania tego co zostało zawarte w jego imieniu i na podstawie wystawionych przez niego pełnomocnictw”. Natomiast E. de Vattel podkreślał, iż umowy zawarte przez władze niższe z przekroczeniem kompetencji zwane w doktrynie XVII- oraz XVIII-wiecznej sponsiones, nabierały - zdaniem ówczesnych prawników - mocy obowiązującej dopiero po ratyfikacji przez monarchę, wyrażonej bądź w sposób wyraźny, bądź przez fakty konkludentne, zob. E. de Vattel, op. cit., s. 476-477. Podobny pogląd wyraził F. Słotwiński. Zdaniem tego autora „ratyfikacja miała w takim przypadku charakter prawotwórczy, decydowała o mocy obowiązującej sponsio, por. F. Słotwiński, Prawo narodów naturalne połączone z praktyka państw europejskich, Kraków 1822, s. 118.

21 C. van Bynkershoek, Questionum iuris publici libro duo (1737), wyd. Classics, t. 2, Oxford - London 1930, rozdz. VII; por. M. Frankowska, Umowy międzynarodowe w formie uproszczonej..., s. 66-67 oraz M. Frankowska, De la pretundue prosomption en faveur de la ratification des traités, RGDIP 1969, nr 73.

22 Por. M. Frankowska, Umowy międzynarodowe w formie uproszczonej..., s. 67 i 222. 
duje ratyfikacja suwerenna", a nie podpisanie umowy przez pełnomocnika - jak uważała większość autorów. Pogląd ten dał jednak początek innemu znaczeniu ratyfikacji ${ }^{23}$.

W tym okresie praktyka państw jednak jeszcze całkowicie potwierdza słuszność poglądów H. Grocjusza i M. de Wicqueforta.

To właśnie w pełnomocnictwach zamieszczano powszechnie klauzule dotyczące przyrzeczenia ratyfikowania wszystkiego, na co zgodzą się pełnomocni$\mathrm{cy}^{24}$. Zwykle czyniono z nich integralną część traktatu ${ }^{25}$.

Ponadto w tekście ówczesnych umów dość często można odnaleźć wyraźne postanowienia dotyczące obowiązku ratyfikacji, którego wykonanie osobiście gwarantowali swym honorem pełnomocnicy ${ }^{26}$. W konsekwencji ratyfikacja $\mathrm{w}$ tym czasie następowała niemal automatycznie po podpisaniu umowy. Wskazuje na to porównanie dat podpisania traktatów z datami ratyfikacji ${ }^{27}$. Należy zauważyć, iż istnienie obowiązku ratyfikacji czyniło z instytucji ratyfikacji de facto instytucję w istocie protokolarną, niemającą zasadniczego znaczenia prawnego w całym procesie zawarcia umowy. Jest zrozumiałe, że taki charakter prawny ratyfikacji sprawiał, iż między umowami zawartymi z pominięciem tego stadium a umowami ratyfikowanymi nie było jakiejś istotniejszej różnicy. Jest bezsporne, iż umowy zawarte bez ratyfikacji występowały już w tym czasie. Wspomina o nich bardzo wyraźnie sam Grocjusz ${ }^{28}$. W konkluzji można stwierdzić, iż

23 Ibidem, s. 222-223.

24 Por. J. M. Jones, op. cit., s. 3. W literaturze przedmiotu często wymienia się przykładowo pełnomocnictwa wystawione przez Annę, królową Wielkiej Brytanii, w związku z zawarciem między tym państwem a Zjednoczonymi Prowincjami Holandii traktatu, podpisanego w Westminster w dniu 9 czerwca 1703 r., zob. Martens, Göttingen 1802, t. 1, s. 22, jak również pełnomocnictwa króla Sardynii wystawione w Turynie w dniu 15 lutego 1720 r. (ibidem, s. 439).

25 Przykładowo tekst pełnomocnictw przytoczony in extenso znajduje się w traktacie dotyczącym granic, podpisanym w Madrycie w dniu 13 stycznia 1750 r. przez przedstawicieli Portugalii i Hiszpanii, zob. J. M. Jones, op. cit., s. 328. Również taki tekst zamieszczono w traktacie pokoju i przyjaźni między Wielką Brytanią, Francją i Hiszpanią, podpisanym w Paryżu w dniu 10 lutego 1763 r., zob. Martens, Göttingen 1817, t. 1, s. 104.

26 Przykładowo wymienić tu można art. 20 traktatu o obronnym przymierzu, podpisanego w Lizbonie w dniu 16 maja 1703 r. między Wielką Brytanią a Stanami Generalnymi Zjednoczonych Prowincji Holandii z jednej strony, a Portugalią z drugiej, który przewidywał, że „Wymienieni pełnomocnicy przyrzekają, że ich wyżej wymienieni suwerenowie ratyfikują ten traktat we właściwej i należnej formie", zob. Martens, t. 1, s. 3. Tej samej treści postanowienie zawierał w art. 3 traktat handlowy podpisany w Lizbonie, przytacza go w swej rozprawie J. M. Jones (zob. idem, op. cit., s. 115).

27 I tak np. traktat dotyczący granic między Portugalią i Hiszpanią, podpisany w dniu 13 stycznia 1750 r. - został ratyfikowany przez Hiszpanię już w dniu 15 stycznia, natomiast przez Portugalię w dniu 26 stycznia 1750 r. (Martens, t. 1, s. 328). Ponadto wiele przykładów w tym zakresie podaje przede wszystkim J. M. Jones (zob. idem, op. cit., s. 115 i nast.).

28 W swym dziele O prawie wojny $i$ pokoju (w rozdziale dotyczącym zobowiązań władz niższych w czasie wojny) Grocjusz w sposób wyraźny dokonuje rozróżnienia między zobowiązaniami zaciągniętymi przez pełnomocnika a zobowiązaniami, które „władze niższe” zaciągają we własnym imieniu. Powtarza za Cezarem: „Inna jest bowiem rola legata, a inna naczelnego wodza; pierw- 
w okresie absolutyzmu właściwym źródłem decyzji dotyczącej zawarcia umowy był zawsze sam suweren, stąd w świetle prawa wewnętrznego wybór takiego, czy innego sposobu zawarcia umowy był sprawą o marginalnym znaczeniu.

W okresie parlamentaryzmu kształtuje się nowoczesne państwo ze złożonym aparatem władzy, a w wyniku rewolucyjnych przemian - monarcha z suwerena staje się jednym z organów suwerennego państwa. Po raz pierwszy kompetencje monarchy określają wewnętrzne ustawy. Jest znamienne przy tym, iż wyłączna do tej pory kompetencja panującego do działań międzynarodowych - zostaje w sposób wyraźny uregulowana. W konsekwencji - co najistotniejsze - zostaje przeważnie ograniczona oraz poddana kontroli władzy ustawodawczej ${ }^{29}$.

I tak, już pierwsza konstytucja pisana wprowadziła regulacje ograniczające swobodę głowy państwa w zakresie zawierania umów. Przepis art. 2 Konstytucji USA z 1789 r. stanowił m.in., iż prezydent „za radą i zgodą Senatu udzieloną większością dwóch trzecich obecnych senatorów może zawierać traktaty”. Kolejne ustawy zasadnicze Republiki Francuskiej - jako pierwsze w Europie - wprowadziły udział organów przedstawicielskich w procesie zaciągania przez państwo zobowiązań międzynarodowych ${ }^{30}$. Już w tym czasie zdawano sobie sprawę - jakie znaczenie ma ograniczenie władzy wykonawczej w tym względzie ${ }^{31}$. Tym samym dawano wyraz przekonaniu o konieczności zapewniania wpływu organu przedstawicielskiego na zobowiązania państwa nie tylko ze względu na ich wagę polityczną, ale przede wszystkim zasadę suwerenności ustawy. Takie podejście stanowiło równocześnie nowe traktowanie umowy międzynarodowej. Był to akt

szy ma działać z rozkazu, drugi zaś układa własny plan działania”. Otóż zdaniem Grojusza „władze niższe” posiadające uprawnienia zbliżone do władzy najwyższej mogą zobowiązywać ją „swoimi działaniami, które wchodzą w zakres ich obowiązków”, jeśli działają „w ramach uprawnień związanych z pełnioną funkcją publiczną" (zob. H. Grocjusz, op. cit. s. 500 oraz 502 i nast.). Jeszcze precyzyjniej pisał o tym de Vattel. „Władze niższe - dowódcy armii i ministrowie [...] na podstawie swej kompetencji mogą także sami zawierać umowy w sprawach publicznych, wykonując $\mathrm{w}$ tej mierze prawo i władzę monarchy, który ich mianował. Tę władzę otrzymują oni dwoma sposobami: albo jest im ona powierzona wyraźnie przez monarchę, albo wynika ona naturalnie $\mathrm{z}$ ich kompetencji, gdyż natura spraw im powierzonych wymaga, żeby moc zawierania podobnych umów, zwłaszcza w wypadkach, gdy nie mogą czekać na rozkazy monarchy". Ponadto Vattel zauważył, że umowy tego rodzaju nabierały mocy obowiązującej bez ratyfikacji, a władze niższe zobowiązywały w sposób definitywny „państwo czy monarchę, który im powierzył władzę”. Inaczej niż to czynił Grocjusz Vattel nie ograniczał umów tego rodzaju jedynie do porozumień zawieranych w czasie prowadzonych działań wojennych. Jednak podkreślał przy tym wyraźnie, iż „umowy takiego rodzaju mają miejsce głównie w czasie wojny" (por. E. de Vattel, op. cit., s. 476 i nast.).

29 Por. O. E. Polenc, op. cit., s. 9 i nast.

30 Bardzo szczegółowo na ten temat pisze B. Mirkine-Guetzevitch w pracy Droit constitutionnel international, Paris 1933, s. 101 i nast.

31 Warto tu przytoczyć znamienne zdanie, jaki wypowiedział w maju 1780 r. Petion Villeneuve na posiedzeniu Zgromadzenia Konstytuanty: „Jeśli władza wykonawcza nie ma prawa wydania najprostszej ustawy, jakże dać jej prawo zawierania traktatów, których konsekwencje są tak poważne”, por. ibidem, s. 100. 
w swych skutkach wewnętrznoprawny analogiczny do ustawy. W konsekwencji w sposób naturalny nastąpiło włączenie organu ustawodawczego do procesu podejmowania decyzji o związaniu się przez państwo traktatem ${ }^{32}$.

Kolejny wiek (XIX) przynosi rozwinięcie przepisów konstytucyjnych w tym względzie. Jest faktem, iż odpowiednie regulacje stosunkowo szybko znalazły się w konstytucjach poszczególnych państw. Ponadto, co istotne - należy wskazać na dwie dość charakterystyczne sprawy. I tak wymaganiem zgody organu ustawodawczego na zawarcie umowy ograniczono kompetencje tylko głowy państwa. Po drugie - zgoda taka poprzedzała wydanie przez głowę państwa aktu ratyfikacji. Wynikało to z faktu, że przytłaczająca większość umów zawierała w tym okresie głowa państwa. Umowy zawierane przez władze niższego szczebla były tak nieliczne i pozbawione znaczenia, że włączanie organu przedstawicielskiego w proces ich zawarcia nie wydawało się konieczne. Były to - jak wskazuje praktyka głównie umowy wojskowe. Uzależnienie ich zawarcia od zgody parlamentu nie znajdowało uzasadnienia. Otóż żadna z konstytucji tego okresu nie zawierała postanowień wyposażających wprost inne organy - poza głową państwa - w kompetencje zaciągania zobowiązań traktatowych.

Ponadto, w związku z ustaloną od dłuższego już czasu praktyką, umowy zawierane przez głowę państwa, były umowami ratyfikowanymi. Tym samym ograniczenie kompetencji głowy państwa polegało na tym, iż zgoda parlamentu poprzedzała akt ratyfikacji dokonywany przez monarchę, czy prezydenta. W rezultacie - ratyfikacja stała się środkiem czynności zabezpieczającej kontrolę działalności państwa $\mathrm{w}$ sferze międzynarodowej przez organy przedstawicielskie.

Nie ulega wątpliwości, iż to właśnie w tym czasie ratyfikacja zmieniła swój charakter prawny. Potwierdzają to zarówno teksty ówczesnych pełnomocnictw, jak i samych traktatów.

Już od najwcześniejszych lat występowania Stanów Zjednoczonych w obrocie międzynarodowym pełnomocnictwa wystawiane przez prezydenta tego

32 Wypada wskazać, iż pierwszym aktem prawnym rewolucji, który dawał początek nowemu systemowi - był dekret Konstytuanty z dnia 22 maja 1790 r., stanowiący w swym artykule 9 „Królowi przynależy ustanawianie i podpisywanie z obcymi mocarstwami wszystkich konwencji potrzebnych dla dobra państwa; traktaty pokoju, przymierza, i traktaty handlowe nie będą wykonane bez ratyfikacji przez ciało ustawodawcze" (por. A. Gwiżdż, Kontrola parlamentarna polityki zagranicznej, cz. I, SM 1967, nr 6, s. 47 i nast. oraz B. Mirkine-Guetzevitch, La technique parlamentaire des relations internationales, RCADI 1936, t., s. 240 oraz 243). Natomiast konstytucja z 1791 r. rozszerzyła w sposób istotny kompetencje ciała ustawodawczego. Zaś konstytucja z 1794 r. stanowiła /w art. 4/, iż traktaty nie są ważne, dopóki nie zostaną zbadane, ratyfikowane i potwierdzone przez Konwent Narodowy (por. ibidem, op. citt., s. 243 oraz B. Mirkine-Guetzevitch, Droit constitutionel..., s. 102-103, również J. M. Jones, op. cit., s. 14). Jest charakterystyczne, iż akt konstytuanty wymagał współpracy organu ustawodawczego $\mathrm{w}$ procesie wykonania określonych tylko kategorii umów, to jednak późniejsze konstytucje nadały organowi legislacyjnemu kompetencje uczestniczenia w procesie zawierania umów międzynarodowych - praktycznie w zakresie maksymalnym. 
kraju zawierały klauzulę zastrzegającą swobodę decyzji - co do ratyfikowania podpisanej umowy ${ }^{33}$. Wspomniana praktyka była stosowana konsekwentnie. Wypada zauważyć, iż już w instrukcji sekretarza stanu sporządzonej w dniu 14 sierpnia 1817 r. dla przedstawiciela dyplomatycznego Stanów Zjednoczonych w Szwecji znajduje się stwierdzenie, że "całkowicie zrozumiałe” jest, iż „podstawową normą" (fundamental law) systemu amerykańskiego jest zasada, zgodnie z którą „każdy traktat zawarty przez ministra Stanów Zjednoczonych, niezależnie od tego, w jakim stopniu postępuje on zgodnie ze swoimi pełnomocnictwami i instrukcjami i niezależnie od postanowień traktatu”, będzie „mógł być zawsze zmieniony lub [ ...] odrzucony przy przedstawieniu go Senatowi do ratyfikacji” ${ }^{34}$.

Natomiast $w$ praktyce państw europejskich przemiany te odzwierciedliły się znacznie później ${ }^{35}$. Przyrzeczenie ratyfikacji znikło z pełnomocnictw brytyjskich dopiero w 1842 r., a w praktyce traktatowej Austro-Węgier przetrwało aż do początków $\mathrm{XX}$ w. ${ }^{36}$

Niejako symetrycznie - do zmian wzorów pełnomocnictw - przebiegała również ewolucja treści klauzul umownych. Stypulacje zapewniające ratyfikację, zamieszczane w traktatach stosunkowo często jeszcze w XVII i XVIII w. zostały zastąpione przez regulacje uzależniające nabranie mocy obowiązującej przez umowę - od dokonania ratyfikacji ${ }^{37}$.

W konsekwencji dotychczasowy obowiązek ratyfikacji ustąpił miejsca swobodzie podjęcia ostatecznej decyzji. Ratyfikacja z aktu o charakterze całkowicie

33 Por. przykładowo pełnomocnictwa wystawione w 1797 r. dla amerykańskich posłów we Francji zawierały postanowienie, że mogą oni „układać się z ministrami [...] Republiki Francuskiej” oraz że wyniki mają być przekazane prezydentowi Stanów Zjednoczonych dla uzyskania jego ostatecznej ratyfikacji za radą i zgodą Senatu Stanów Zjednoczonych, jeśli ta zgoda zostanie wyrażona, por. J. M. Jones, op. cit., s. 14 i 114.

34 Por. J. B. Moore, Digest of International Law, Washington 1906, s. 199.

35 Już w pełnomocnictwach wystawionych przez rząd francuski w 1792 r. ambasadorowi w Szwajcarii, które upoważniły go do zawarcia traktatu z Prusami, zaznaczono wyraźnie: „Przedstawiciele narodu francuskiego [...] dają mu pełnomocnictwa do prowadzenia rokowań w imieniu Republiki [...] i zawarcia pokoju tylko pod warunkiem ratyfikacji". Natomiast w instrukcjach przekazanych ambasadorowi dodano, iż powinien on „uprzedzić pruskich pełnomocników o tym, że traktat pokoju, jeśli będzie zawarty, będzie wymagał ratyfikacji przez Konwent Narodowy. Jednak w okresie Napoleona pełnomocnictwa francuskie wróciły do wzorów z okresu absolutyzmu. I znów zawierały one przyrzeczenia ratyfikacji. Dopiero definitywnie formę tę zarzucono po restytucji monarchii konstytucyjnej, por. J. M. Jones, op. cit., s. 14-15.

36 Por. ibidem, s. 15 oraz L. Bittner, Die Lehre von den völkerrechtlichen Vetragsurkunden, Berlin Leipzig 1924, s. 136 i nast.

37 W doktrynie zaznacza się, iż jednym z pierwszych przykładów takiej nowej regulacji - może być przepis art. 7 konwencji w sprawie odszkodowania dla obywateli stron, podpisanej w Madrycie w dniu 11 sierpnia 1802 r. między Hiszpanią a Stanami Zjednoczonymi, który wyraźnie stanowił: „Niniejsza konwencja nie będzie miała mocy obowiązującej aż do czasu, gdy zostanie ratyfikowana przez umawiające się strony", por. Martens, Göttingen, t. IX, s. 400. 
formalnym - stała się aktem prawotwórczym, rozstrzygającym ostatecznie o nabraniu przez umowę mocy obowiązującej ${ }^{38}$.

W okresie, gdy sposób zawarcia umowy międzynarodowej staje się bardziej rygorystyczny niż w poprzedniej epoce oraz gdy kształtuje się zasada, że nie podpisanie umowy, a dopiero jej ratyfikacja decyduje o nabraniu przez umowę mocy obowiązującej - coraz liczniej pojawiają się porozumienia, które dochodzą do skutku bez ratyfikacji (bowiem dla swej ważności wcale jej nie wymagają). Z czasem ta grupa umów przyjmie nazwę - „umów w formie uproszczonej" 39 .

Ponadto, $\mathrm{w}$ tym czasie wykształciła się również inna procedura zawarcia umowy w trybie złożonym, zgodnie z którą akt ratyfikacji zastępowany był aktem zatwierdzenia - dokonywanym bądź przez zainteresowane rządy, bądź przez ministra spraw zagranicznych. Współcześnie można byłoby określić tę procedurę, jako instytucję zatwierdzenia umowy w klasycznej postaci ${ }^{40}$.

Ostatnie dziesiątki lat XIX w., jakkolwiek nie wnoszą wiele w zakresie zmian charakteru prawnego samej instytucji ratyfikacji, to w tym czasie zachodzą poważne zmiany w charakterze stosunków między państwami - prawo międzynarodowe przekształca się z prawa wojny i pokoju - w prawo, którego przedmiotem regulacji staje się przede wszystkim szeroko rozumiana pokojowa współpraca międzynarodowa ${ }^{41}$.

W efekcie następuje proces specjalizacji obrotu traktatowego państw, odpowiadający narastającej tendencji do decentralizacji i specjalizacji wewnętrznych uprawnień władzy wykonawczej. Szybko okazuje się, że potrzeba współdziałania międzynarodowego występuje w coraz to nowych dziedzinach życia, nowych nie tylko dla regulacji między państwami, ale i dla prawnej regulacji stricte stosunków wewnętrznych państw ${ }^{42}$. Błyskawicznie rozwijająca się współpraca między państwami oraz rozszerzenie się zasięgu wzajemnych stosunków, a przy tym nasilenie się ich częstotliwości, znalazły wyraz nie tylko w zwiększeniu ilości traktatów i wykształceniu się nowych sposobów zawarcia umowy, ale i również nowych rodzajów umów, w tym umów w formie uproszczonej ${ }^{43}$. Jednak przez

38 Por. J. M. Jones, op. cit., s. 114 i nast.

39 Por. M. Frankowska, Umowy międzynarodowe w formie uproszczonej..., s. 75 i nast.

40 Ibidem, s. 83 i nast.

41 Por. M. Lachs, Umowy wielostronne, Warszawa 1958, s. 13 i 255; S. E. Nahlik, Wstęp do nauki prawa traktatów, Warszawa 1967, s. 101. Warto podkreślić, że jeszcze dla autorów połowy XIX w. „umowy między narodami to zwykle traktaty pokoju i takie traktaty, które dotyczą wojny i pokoju" - cyt. za: M. Lachs, op. cit., s. 255. Na przestrzeni ponad 33 wieków (od 1500 p.n.e. do 1850 n.e.) - jak przedstawia to Ompteda - zawarto ok. 8000 traktatów pokoju - D. Von Ompteda, Literatur des Völkerrecht, Regensburg 1789, s. 583.

42 Zob. M. Lachs, op. cit., s. 255 oraz S. Hubert, Zarys rozwoju nowoczesnej społeczności międzynarodowej, Kraków 1947, s. 86 i nast.

43 Por. S. E. Nahlik op. cit., s. 103 i nast. Jest znamienne, iż zachodzące przemiany nie wpłynęły jednak w sposób zasadniczy i widoczny na formę umownego regulowania stosunków międzynarodowych. 
kilkadziesiąt jeszcze lat umowy zawarte bez ratyfikacji należeć będą raczej do wyjątków, a ich znaczenie w owym czasie będzie mieć charakter marginalny ${ }^{44}$.

Jeszcze w okresie XIX w. większość zagadnień współpracy międzynarodowej regulowana jest $\mathrm{w}$ formie traktatów solennych. Do instytucji ratyfikacji - jako sposobu uprawomocnienia się umowy przywiązuje się w tym czasie ogromne znaczenie. Ważną ilustracją prawną tej tezy jest m.in. sformułowanie zamieszczone w jednej z uchwał kongresu berlińskiego z $1878 \mathrm{r}$. Zgodnie $\mathrm{z}$ jej treścią „moc ostateczną traktatom nadaje ratyfikacja, a nie podpisanie umowy" ${ }^{45}$. Stąd nic dziwnego, że w tym okresie sprawy nawet zupełnie drobne i wyjątkowo szczegółowe regulowane były w formie traktatów solennych ${ }^{46}$. Ten stan rzeczy ulegał stopniowo systematycznym zmianom na przełomie XIX i XX w. Już w tym okresie większość państw zawarcie traktatu łączy $\mathrm{z}$ wymaganiem uzyskania zgody od ciała ustawodawczego. Zgoda ta często jest zależna w ogromnej mierze od konstelacji politycznej, stopnia poparcia, jakim parlament darzy władzę wykonawczą, a to $\mathrm{z}$ kolei zależy od układu sił $\mathrm{w}$ tym organie. W konsekwencji często powolna, w samym przebiegu również skomplikowana oraz niedająca się przewidzieć w swym rezultacie końcowym procedura zawarcia traktatu, zostaje coraz częściej zastępowana inną, prostszą, której skutek władza wykonawcza może z góry przewidzieć.

Stąd stopniowo i konsekwentnie forma traktatu solennego (wymagającego ratyfikacji) staje się mało dogodnym narzędziem regulowania przez władzę wykonawczą stosunków z innymi państwami i jest skutecznie wypierana przez umowy $\mathrm{w}$ formie uproszczonej (umowy zawierane bez ratyfikacji). Wszystkie wskazane względy działają na rzecz kształtowania i rozwoju innych niż ratyfikacja sposobów (procedur) zawierania umów międzynarodowych. W rezultacie sprzyjają dość wyraźnie rozwojowi umów w formie uproszczonej - tj. wzrostu ilościowego oraz rozszerzenia katalogu spraw przez nie regulowanych.

Można - za doskonałym znawcą praktyki traktatowej państw (tego okresu), L. Bittnerem, który po wnikliwych badaniach umów zawartych na przełomie XIX i XX w. - stwierdzić, iż „w owym okresie powoli zacierała się dotąd wyraźna granica oddzielająca sprawy regulowane $\mathrm{w}$ formie traktatów od spraw regulowanych w drodze umów w formie uproszczonej ${ }^{47}$. Jednak w ocenie

W istocie proporcjonalnie do wzrostu ilości traktatów - ilość umów w formie uproszczonej nie uległa zauważalnemu zwiększeniu.

44 Formę uproszczoną miały najczęściej porozumienia dodatkowe, związane bezpośrednio lub pośrednio z zawartym poprzednio traktatem: umowy wykonawcze, umowy towarzyszące zawarciu traktatu, umowy dotyczące stosowania postanowień traktatu oraz umowy (mające jednak znacznie ważniejszą od wymienionych rangę) zmieniające poprzednio zawarty traktat, por. M. Frankowska, Umowy międzynarodowe $w$ formie uproszczonej..., s. 83-84.

45 Por. protokół nr 19, cyt. za: Martens, Göttingen 1878-1879, t. 2, s. 445.

46 Por. M. de Clerq, t. VIII, s. 618 i 748 oraz t. IX, s. 148; zob. też: M. Frankowska, Umowy międzynarodowe $w$ formie uproszczonej..., s. 86.

47 Zob. L. Bittner, op. cit., s. 26 i nast.; por. M. Frankowska, Umowy międzynarodowe w formie uproszczonej..., s. 87. 
M. Frankowskiej - lektura zbiorów umów międzynarodowych owego okresu zarówno Martensa czy de Clerqa - jeszcze do takich ostatecznych wniosków nie upoważniała ${ }^{48}$. Tym niemniej, Bittner, analizując praktykę austriacką, wskazał na taką tendencję występującą już w tym czasie. Znalazła ona potem wyraźne potwierdzenie w praktyce stosunków traktatowych innych państw.

Należy podkreślić, iż szczególnego rozmachu i znaczenia nabiera w omawianym okresie praktyka executive agreements - umów zawieranych przez rząd Stanów Zjednoczonych na mocy upoważnienia Kongresu, a dotyczących ochrony własności przemysłowej i literackiej, zagadnień celnych oraz innych kwestii związanych z szeroko rozumianą współpracą handlową ${ }^{49}$.

Ponadto w tym czasie ustala się pewna grupa zagadnień współpracy międzynarodowej, regulowana przede wszystkim przez umowy niewymagające ratyfikacji ${ }^{50}$. Bez ratyfikacji stały się wiążące umowy, które regulowały sprawy związane $\mathrm{z}$ formalnościami dotyczącymi ruchu osobowego, kwestie dotyczące statusu marynarzy oraz wiele spraw o charakterze administracyjnym ${ }^{51}$. Bez ratyfikacji zawierano również porozumienia związane z wcześniej zawartym traktatem, w tym w szczególności dwa nowe rodzaje umowy: porozumienia interpretacyjne oraz przedłużające moc obowiązującą traktatów.

W okresie międzywojennym - choć traktaty nadal stanowią jeszcze przeważającą grupę umów, a ratyfikacja jest główną procedurą uprawomocnienia się umowy - w rezultacie obserwujemy zjawisko utrwalania się w praktyce innych niż ratyfikacja sposobów wyrażania przez państwo zgody na związanie się umową. Jakkolwiek traktaty solenne stanowią jeszcze ponad połowę zawieranych umów, to wspomniane zjawisko łączy się bezpośrednio ze wzmocnieniem władzy wykonawczej wobec legislatywy ${ }^{52}$. Jednak bardziej gwałtowna zmiana w tym zakresie nastąpiła dopiero po drugiej wojnie światowej.

48 M. Frankowska, Umowy międzynarodowe w formie uproszczonej..., s. 87.

49 Por. F. O. Wilcox, op. cit., s. 214-215.

50 Por. L. Bittner, op. cit., s. 31 i nast.

51 Szerzej o tym pisze M. Frankowska, Umowy międzynarodowe w formie uproszczonej..., s. 88-89.

52 Wspomnianą ocenę pozwalają sformułować dane opracowane przez F. Wilcoxa i H. Blixa na podstawie rejestru Ligi Narodów, jak również dane z praktyki Stanów Zjednoczonych i Polski. I tak, według informacji, które przytacza F. Wilcox: „na pierwszy tysiąc umów zarejestrowanych w Lidze Narodów w okresie pięcioletnim (LNTS tomy 1-39) - 280 umów w formie jednego dokumentu zawarto bez wymagania ratyfikacji, natomiast 213 umów ujęto w formę not, najczęściej nieprzewidujących ratyfikacji (por. F. O. Wilcox, op. cit., s. 213 i 214). Hans Blix dokonał badań tego samego rejestru w okresie późniejszym 1932-1940, stwierdzając podobne wielkości - 53\% stanowiły traktaty oraz $47 \%$ umowy zawarte bez ratyfikacji (por. H. Blix, The Requirement of Ratification, „British Yearbook of International Law" 1953, t. 30, s. 362). 


\section{Brak domniemania (presumpcji) ratyfikacji}

Generalnie umowy międzynarodowe w swych postanowieniach końcowych zawierają obecnie klauzule, które ustalają sposób uzyskania przez nie mocy obowiązującej. Jednak nie oznacza to, iż w praktyce traktatowej państw nie występowały i nie występują nadal umowy, które nie określają sposobu swego uprawomocnienia, zaś kwestia sposobu, w jaki nabierają one mocy wiążącej jest jasno rozstrzygnięta ${ }^{53}$. Jedyna norma pisana regulująca to zagadnienie nie ma już dzisiaj w praktyce żadnego znaczenia. Zawierał ją art. 5 konwencji hawańskiej z 20 lutego 1928 r. o prawie traktatów. Zgodnie z jego brzmieniem „traktaty stają się obowiązujące jedynie po ratyfikacji przez umawiające się państwa, nawet wówczas, gdy taki warunek nie jest ustalony ani w pełnomocnictwach przedstawicieli, ani w samym traktaci ${ }^{54 "}$. Stąd spory od dawna toczące się na ten temat $\mathrm{w}$ doktrynie są dla rozważań i badań nad instytucją ratyfikacji niezwykle istot$\mathrm{ne}^{55}$. Koncentrowały się one z reguły wokół zagadnienia - czy ratyfikacja w takich przypadkach jest, czy też nie jest wymagana. Jest charakterystyczne, iż to kluczowe zagadnienie było konsekwentnie łączone $\mathrm{z}$ obowiązywaniem tzw. zasady presumpcji ratyfikacji, a to $\mathrm{z}$ kolei stanowiło główny powód do wyodrębnienia kategorii umów międzynarodowych, które tej zasadzie miały nie podlegać. W rezultacie, co podkreślali inni, fakt taki pozbawiał obowiązywania wspomnianej zasady jakiegokolwiek istotnego znaczenia ${ }^{56}$.

Wydaje się, iż przedstawienie ewolucji poglądów w tej dziedzinie jest całkowicie uzasadnione i warto jednak zwrócić uwagę, iż łączy się ono ściśle z zasadniczymi przemianami ustrojowymi współczesnych państw. Wspomniane przemiany zmieniły nie tylko charakter i znaczenie wielu instytucji prawa traktatów, ale i doprowadziły konsekwentnie do wyodrębnienia w praktyce obok traktatów solennych umów w formie uproszczonej. To one wreszcie ukształtowały zasadę odmienną - braku obowiązku ratyfikacji w przypadku, kiedy umowa międzynarodowa wprost nie przewiduje, w jaki sposób się uprawomocnia ${ }^{57}$.

Tradycyjnie początek kontrowersji odnośnie obowiązywania zasady presumpcji ratyfikacji (czy też braku jej obowiązywania) jest wywodzony od czasów polemiki C. van Bynkershoeka z poglądami H. Grocjusza ${ }^{58}$. To właśnie van Bynkershoek twierdził, iż o definitywnym zawarciu umowy decyduje ratyfikacja dokonana przez suwerena, a nie - jak w tym właśnie czasie utrzymywano -

53 Por. M. Frankowska, De la predendue presumption...

54 Tekst projektu zamieszczony został w AJIL z 1935 r., t. 29, Supplement, s. 1205.

55 Ibidem.

56 Por. M. Frankowska, Umowy międzynarodowe w formie uproszczonej..., s. 222.

57 Ibidem.

58 C. van Bynkersheok, Qestionum iuris publici libri duo (1737)..., s. 228-235. Poglądy Bynkershoeka podzielali A. Gentilis i M. de Wicquefort. 
podpisanie umowy przez pełnomocnika. Zaznaczał on przy tym, iż choćby wyraźnie nie stwierdzono o tym ani w pełnomocnictwach, ani w postanowieniach porozumienia, to ratyfikacja zdaniem tego autora była niezbędnym warunkiem skutecznego zawarcia umowy ${ }^{59}$. Jak pisał: „Stało się niemal powszechnym zwyczajem, aby nie uznawać traktatów i paktów zawartych przez ambasadorów za ważne, dopóki monarchowie, których oni reprezentowali, nie potwierdzili tych aktów ostatecznie" ${ }^{\prime \prime}$. Jest znamienne, iż pogląd ten wymierzony przeciw panującej ówcześnie teorii mandatu, nabrał w okresie późniejszym zupełnie odmiennego znaczenia. Został uznany za ważny argument obrony na rzecz ratyfikacji w jej nowym kształcie prawno-ustrojowym, określonym przez przepisy pierwszych ustaw zasadniczych Stanów Zjednoczonych i Francji. Dopiero wtedy zyskał wielu zwolenników.

I tak Ch. Calvo wymaganie ratyfikacji określał jako „zasadę ogólną i absolutną", od której odstępstwa nie wolno nigdy domniemywać ${ }^{61}$. Natomiast A. Rivier pisał, iż „ustalił się obyczaj, aby zastrzegać wymaganie ratyfikacji w samym traktacie. Jednakże wówczas, gdy takie zastrzeżenie nie jest wyraźnie zaznaczone $\mathrm{w}$ traktacie, należy je domniemywać, a tym samym zamiar uzależnienia ważności traktatu od ratyfikacji przez strony umowy jest domniemany" ${ }^{2}$. Podobne opinie w późniejszym okresie prezentowali m.in. F. Dehousse, P. Fauchille, L. Oppenheim, Ch. Rousseau, A. D. McNair, F. Berber ${ }^{63}$, zaś z polskich autorów J. Makowski, L. Ehrlich oraz K. Libera ${ }^{64}$. Żaden właściwie z wymienionych zwolenników zasady presumpcji ratyfikacji nie odnosił jej w ten sposób do wszystkich w ogóle umów międzynarodowych. Zazwyczaj wspomniani autorzy ograniczali zastosowanie tego domniemania do najważniejszych kategorii umów międzynarodowych. Można zauważyć, iż czynili to dwojako. I tak jedni, jak przykładowo P. Freymond oraz R. Lapidoth, najpierw dokonywali generalnego podziału wszystkich umów międzynarodowych na dwie grupy: traktaty i umowy

59 Ibidem.

60 Ibidem, s. 234.

61 Por. Ch. Calvo, Le droit international, vol. III, Paris - Berlin 1888, s. 382.

62 Por. A. Rivier, Pricipes du droit des gens, t. 2, Paris 1869, s. 71-72.

63 Por. P. Fauchille, Traite de droit international public, t. 1, Paris 1926, s. 318-320; F. Dehousse, La conclusion des traités d'après la pratique constitutionnelle et diplomatique belge, „Annales de l'Institut de droit compare de l'Universite de Paris" 1938, t. 3 s. 82 i nast. Prezentowane przez Dehousse stanowisko - w tym czasie najlepiej uzewnętrzniało stan poglądów nauki prawa międzynarodowego, które określić można by dzisiaj mianem - nowoczesnych (por. F. Dehousse, op. cit., s. 88); zob. też: L. Oppenheim, International Law (wyd. VIII - H. Lauterpachta), t. 1, London 1955, s. 903 i nast.; Ch. Rousseau, Principes generaux de droit international public, t. 1. Paris 1944, s. 189; A. D. McNair, The Law of Treaties, Oxford 1961, s. 133-134; F. Berber, Lehrbuch des Völkerrecht, t. 1, München 1960, s. 423 i nast.

64 Por. J. Makowski, Organa państwa w stosunkach międzynarodowych. Zjazdy i konferencje międzynarodowe. Umowa międzynarodowa, Warszawa 1957, s. 173; L. Ehrlich, Prawo międzynarodowe, Warszawa 1958, s. 248 i nast.; zob. też: C. Berezowski, W. Góralczyk, K. Libera, Prawo międzynarodowe publiczne, Warszawa 1967, s. 84. 
uproszczone, przy czym te ostatnie określali, jako umowy zawarte bez potrzeby ratyfikacji. Jednak ich argumentacja nie była konsekwentna, bowiem w konkluzji stwierdzali, że istnieje w prawie międzynarodowym zasada w myśl której domniemanie przemawia na rzecz ratyfikacji umów międzynarodowych ${ }^{65}$. Wypada zaznaczyć, iż w tym czasie, tak uzasadniona reguła, nie może mieć w istocie znaczenia praktycznego, a walor takiego uzasadnienia ma jedynie znaczenie poznawcze. Natomiast rozumowanie drugiej grupy najlepiej charakteryzuje teza L. Oppenheima. Autor ten wyraźnie zauważał, że „chociaż jest obecnie powszechnie uznaną normą prawa międzynarodowego to, że traktaty wymagają zwykle ratyfikacji, nawet wówczas, gdy nie posiadają w tej kwestii wyraźnej regulacji, to jednak istnieją odchylenia od tej normy" ${ }^{66}$. Oppenheim do wspomnianych „odchylen”” zaliczał:

1) umowy zawarte przez takie osoby, które $z$ racji pełnienia określonych funkcji państwowych mogą zobowiązywać państwo bez specjalnych pełnomocnictw,

2) umowy zawarte w pewnej szczególnej formie, np. protokół, deklaracja, wymiana not, modus vivendi,

3) porozumienia dotyczące spraw o mniejszym znaczeniu ${ }^{67}$.

Natomiast J. Makowski wyliczał następujące kategorie umów w odniesieniu do których nie ma zastosowania zasada presumpcji ratyfikacji. Były to:

1) umowy resortowe

2) umowy o rozejmie, zawieszeniu broni,

3) inne umowy kartelowe,

4) gentelmens agreements,

5) umowy noszące specjalne nazwy, jak: arrangement, deklaracje, memorandum d accord itp. ${ }^{68}$

Wypada stwierdzić, iż tak ujęta argumentacja - abstrahując od tego czy można się z nią zgodzić, czy też nie - jest logiczna i konsekwentna. Delimituje konkretny zakres obowiązywania zasady domniemania wymagania ratyfikacji, a ponadto i co wydaje się bardzo istotne - w ogóle umożliwia odniesienie tego domniemania do praktyki międzynarodowej ${ }^{69}$. Jednak dla wszystkich wymie-

65 Por. P. Freymond, La ratification des traitès et le probléme des rapports entre le droit international et de le droit interne, Lozanne - Paris 1947, s. 25 i 53; zob. też: R. Lapidoth, La coclusion des traitès internationaux en Israel, Paris 1962, s. 16 i nast. oraz D. Anzilotti, Cours de droit international, Paris 1929, s. 368 i 370 .

66 Por. L. Oppenheim, op. cit., s. 906.

67 Ibidem, s. 906-908.

68 J. Makowski, Organa państwa..., s. 173.

69 Takie określenie wyjątków od zasady wymagania ratyfikacji znalazło później swoje odbicie podczas próby zdefiniowania umów w formie uproszczonej przez Komisje Prawa Międzynarodowego, por. Yearbook of ILC, 1962, vol. II, s. 161; zob. też: M. Frankowska, Umowy międzynarodowe $w$ formie uproszczonej..., s. 27 i $224-225$. 
nionych autorów niejako rzeczą wspólną było to, iż w ich ocenie nie ulegało wątpliwości, że ratyfikacja jest najbardziej naturalnym i koniecznym sposobem zawarcia umowy. Natomiast domniemanie ratyfikacji było przez nich kojarzone, jako logiczny rezultat ogólnie obowiązującej zasady wymagania ratyfikacji ${ }^{70}$. Argumenty, jakie przytaczali zazwyczaj zwolennicy domniemania ratyfikacji były, lakonicznie rzecz ujmując, następujące:

a) cywilistyczna teoria mandatu nie nadaje się do dalszego stosowania w stosunkach międzynarodowych,

b) materia spraw regulowana przez umowy międzynarodowe jest tak ważna, że należy umożliwić władzom państwa ich powtórną analizę,

c) ratyfikacja uniemożliwia zawarcie umowy z pogwałceniem pełnomocnictw,

d) instytucja ratyfikacji chroni zdobycze ustroju parlamentarnego (zasada podziału władz), w rezultacie umożliwia kontrolę polityki traktatowej państwa, realizowaną przez egzekutywę.

Jest charakterystyczne, iż żadnemu z tych argumentów nie można odmówić znaczenia, gdy chodzi o wskazanie i uzasadnienie charakteru prawnego samej instytucji ratyfikacji. Prezentowana argumentacja ma też swoje znaczenie, gdy chodzi o ocenę praktyki zawierania umów w inny - niż ratyfikacja - sposób (np. w postępowaniu jednostopniowym). Jak wydaje się, jednak słusznie można mieć wątpliwości, czy są to argumenty wystarczające do uznania ratyfikacji za konieczną i wymaganą w przypadkach umów, które wyraźnie nie określają w jaki sposób stają się dla państwa prawnie wiążące. Należy podkreślić, iż żaden $\mathrm{z}$ podnoszonych $\mathrm{w}$ doktrynie względów, nie przeszkodził powstaniu innych niż ratyfikacja sposobów wyrażania przez państwo zgody na związanie się z umową. Również żaden z nich nie mógł zapobiec zjawisku, aby umowy zawarte zgodnie $\mathrm{z}$ wolą stron $\mathrm{z}$ pominięciem ratyfikacji, stanowiły obecnie zdecydowaną większość porozumień międzynarodowych. W konsekwencji nie można wskazać żadnego też istotnego powodu, aby przedstawione argumenty miały przesądzić o wymogu ratyfikacji nielicznych w końcu i z pewnością nie najważniejszych umów międzynarodowych, które nie zawierają w swych postanowieniach końcowych wyraźnych stypulacji, wskazujących na to, jak miały stać się wiążące dla stron. Z czasem teoria presumpcji ratyfikacji zaczęła tracić na znaczeniu. W doktrynie zaczęły pojawiać się co raz częściej odmienne poglądy.

Początkowo przeciwnicy teorii domniemania ratyfikacji byli nieliczni. Jednak dziewiętnastowieczni przedstawiciele nauki prawa narodów dla poparcia swojej teorii nadal prezentowali argumentację zbliżoną do grocjuszowskiej. Pewne zmiany w tym względzie wprowadziła oryginalna koncepcja G. Fitzmaurice’a zgłoszona w $1934 \mathrm{r}^{71}$

70 Por. M. Frankowska, Umowy międzynarodowe w formie uproszczonej..., s. 225.

71 Por. G. Fitzmaurice, Do Treaties Need Ratifikation?, BYBIL, 1943, s. 124-125. 
W swej rozprawie Czy traktaty wymagaja ratyfikacji autor ten stwierdził, iż „z faktu, że państwa zamieszczają w umowach klauzule dotyczące wymagania ratyfikacji, wyciągnąć można jedynie taki wniosek, iż państwa nie sądzą, aby istniała jakaś ogólna norma uzależniająca nabranie przez umowy mocy obowiązującej od ratyfikacji”. Zdaniem G. Fitzmaurice’a "państwa zdają zachowywać się w taki sposób, jakby nie było żadnej określonej reguły lub raczej, jakby ta norma była zupełnie odmienna"72. Logika takiego rozumowania byłaby zachowana, gdyby faktycznie w praktyce traktatowej występowały wyłącznie umowy, które wyraźnie przewidują ratyfikację, jako warunek ich dojścia do skutku oraz porozumienia, które nie zawierają żadnych klauzul określających sposób ich uprawomocnienia. Jednak w obrocie międzynarodowym występują umowy, i to w znacznie większej ilości od umów wymagających ratyfikacji, które przewidują bezpośrednio tylko podpisanie - jako sposób ich zawarcia.

Jest znamienne, iż stosując argumentację G. Fitzmaurice’a i analizując praktykę zawierania umów międzynarodowych należałoby jednak sformułować wniosek przeciwny. Warto zauważyć, iż stanowisko G. Fitzmaurice’a, choć przez doktrynę odnotowane, nie wywarło na nią jakiegoś zasadniczego wpływu. Praktycznie wszyscy współcześni przeciwnicy teorii domniemania ratyfikacji opierają zwykle swą argumentację na spostrzeżeniu wynikającym z praktyki, iż większość umów uprawomocnia się aktualnie bez potrzeby (wymagania) ratyfikacji ${ }^{73}$.

Należy wskazać, że i ten argument - choć zawierający elementy racjonalne - nie ma charakteru jednoznacznego. Wydaje się, że z faktu, iż większość umów uprawomocnia się w ten czy inny sposób, wcale nie wynika, iż określona procedura zawarcia umowy jest właściwa w przypadku umowy, która nie zawiera stosownej stypulacji, w jaki sposób nabiera ona mocy obowiązującej.

Należy zgodzić się z poglądem M. Frankowskiej, iż ustalenie treści normy międzynarodowej w tej materii „można dokonać w oparciu o badanie odnoszącej się do tego przypadku praktyki państw"74. Należy ustalić przede wszystkim, jak zachowują się państwa w odniesieniu do umów nieregulujących w ogóle sposobu zawarcia umowy ${ }^{75}$.

Badanie praktyki państw w przedmiocie zawierania umów międzynarodowych, które nie mają klauzul dotyczących nabrania mocy obowiązującej, wskazuje, że przeszła ona istotną ewolucję. Nie da się zaprzeczyć, iż w szczególności w XIX w. państwa ratyfikowały niejednokrotnie umowy, które nie posiadały

72 Ibidem.

73 Por. przykładowo: G. Dahm, Völkerrecht, t. III, Stuttgart 1958, s. 78, czy S. E. Nahlik, O wejściu w życie umowy międzynarodowej, „Zeszyty Naukowe Uniwersytetu im. M. Kopernika w Toruniu. Prawo II" 1965, z. 5, s. 103 i nast.

74 Por. M. Frankowska, Umowy międzynarodowe w formie uproszczonej..., s. 227.

75 Ibidem. 
żadnych odnośnych klauzul ${ }^{76}$. Również spostrzeżenie takie jest aktualne w kilku pierwszych dekadach XX w. ${ }^{77}$ Zawsze jednak uzasadnione pozostaną wątpliwości, czy kiedykolwiek znalazła potwierdzenie w obrocie traktatowym państw teza w myśl której „odstępstwa od zasady, że umowa nie jest ważna, dopóki nie jest ratyfikowana, nie wolno nigdy domniemywać ${ }^{78}$.

Bez trudu w praktyce traktatowej państw w tym okresie można znaleźć wiele przykładów umów, które nie mając odpowiednich przepisów, stawały się wiążące $\mathrm{w}$ postępowaniu jednostopniowym ${ }^{79}$. Wydaje się, że nie jest $\mathrm{w}$ ogóle możliwe wskazanie prawdziwości tezy, iż państwa stosowały zasadę domniemania ratyfikacji $\mathrm{w}$ okresie międzywojennym. $Z$ badań przeprowadzonych przez H. Blixa wynika wyraźnie, że przeważająca ilość umów tego rodzaju nabierała mocy obowiązującej bez ratyfikacji. Warto wskazać za tym autorem, iż spośród 72 umów w formie wymiany not ani jednej nie ratyfikowano.

Natomiast w odniesieniu do umów w formie jednego dokumentu zdecydowana większość tego rodzaj umów nabierała mocy wiążącej bez ratyfikacji. Jedynie pięć takich porozumień poddano procedurze ratyfikacyjnej ${ }^{80}$.

Okres drugiej wojny światowej przynosi wiele przykładów zawierania umów międzynarodowych, często o strategicznym znaczeniu, które nie zawierając klauzul dotyczących wejścia w życie - stawały się obowiązujące bez ratyfikacji. Procedura zawarcia tych umów sprowadzała się wyłącznie do jednostopniowego postępowania. Wprost klasycznymi przykładami takich umów są zarówno Karta Atlantycka z 1941 r., jak i umowa zawarta między trzema mocarstwami w Teheranie 1943 r., umowa jałtańska z 1945 r. czy wreszcie układ poczdamski z 1945 r.

Obserwacja praktyki po drugiej wojnie światowej daje asumpt do twierdzenia, że zachowania państw są w tym przedmiocie wyraźnie jednolite. Wskazują na to jednoznacznie rezultaty badań H. Blixa, M. Frankowskiej oraz rezultaty badań własnych. I tak wyniki badań Blixa obejmujące 1300 umów, które zostały opublikowane w zbiorze umów ONZ w latach 1946-1951 ujawniają, iż 125 umów $\mathrm{w}$ formie wymiany not i 50 umów w formie jednego dokumentu nie zawierało klauzul dotyczących sposobu ich uprawomocnienia się. Z grupy tej - liczącej aż 175 umów - jedną tylko umowę $\mathrm{w}$ formie wymiany not poddano procedurze jednostronnej ratyfikacji, natomiast również tylko jedna umowa $\mathrm{w}$ formie jednego dokumentu nabrała mocy wiążącej po procedurze zatwierdzenia ${ }^{81}$.

76 Można wskazać np. na porozumienie między Wielką Brytanią a Chinami, podpisane w Londynie w dniu 18 lipca 1885 r. (por. Martens, Göttingen 1887, t. XII s. 707).

77 Por. L. Le Fur, G. Chklaver, Recueil de textes de droit international public, Paris 1943, s. 611.

78 Zob. Ch. Calvo, op. cit., s. 382.

79 Por. M. Frankowska, Umowy międzynarodowe w formie uproszczonej..., s. 228.

80 Zob. H. Blix, op. cit., s. 366.

81 Ibidem, s. 367. 
Jeszcze bardziej interesująco prezentują się wyniki badań przeprowadzone przez M. Frankowską. Wspomniana autorka objęła nimi praktykę traktatową 38 państw - głównych kontrahentów stosunków traktatowych oraz dwóch organizacji międzynarodowych w latach $1963-1965^{82}$.

Frankowska zbadała w sumie 1579 umów. Spośród tej liczby - 151 umów było bez klauzuli wejścia w życie. Przeważającą większość (bo aż 116) stanowiły umowy zawarte między państwem a organizacją międzynarodową. Natomiast umowy międzypaństwowe zawarte bez odnośnych klauzul były stosunkowo nieliczne (35 umów) - stanowiąc ogółem 2,2\% zbadanych umów.

W ocenie autorki nie jest to wcale ilość znikoma. Nierzadko wspomniane umowy dotyczyły kwestii o istotnym znaczeniu ${ }^{83}$. Wypada zaznaczyć, iż wśród wspomnianych umów znalazły się także dwie umowy wielostronne ${ }^{84}$. Umowy dwustronne w 14 przypadkach ujęte były w formę jednego dokumentu, w 19 były ujęte $\mathrm{w}$ formę wymiany not. Na podkreślenie zasługuje fakt, iż wszystkie te umowy nabrały mocy obowiązującej w postępowaniu jednostopniowym. Nie było wśród nich ani jednej, która zostałaby poddana procedurze ratyfikacji ${ }^{85}$. W konkluzji komentarza do przedstawionych wyników badań należy podkreślić, że świadczą one, iż brak w umowie postanowienia określającego sposób, w jaki ma ona nabrać mocy obowiązującej, wskazuje na zamiar państw, aby taka umowa stała się wiążąca właśnie w postępowaniu jednostopniowym. Tym samym dochodziły one do skutku bez potrzeby ratyfikacji. Zatem można stwierdzić, że we współczesnym prawie międzynarodowym ukształtowała się odmienna zasada, bowiem praktyka potwierdza, iż zasada presumpcji ratyfikacji została odrzucona w obrocie międzynarodowym. Jej miejsce zajęła odmienna zasada presumpcji jednostopniowej formy wyrażania zgody na zawiązanie się umową w takich przypadkach.

W traktacie prac kodyfikujących prawo traktatów w KPM (Komisja Prawa Międzynarodowego) stanowiska jej czterech kolejnych referentów w tej spra-

82 Wszystkie umowy zarejestrowane zostały w Sekretariacie ONZ. Wspomniane dwie organizacje to: Międzynarodowy Bank Odbudowy i Rozwoju oraz ONZ. Warto wskazać, iż właśnie pierwsza $\mathrm{z}$ wymienionych organizacji była najczęściej stroną umowy.

83 Przykładowo wymienić tu można protokół porozumienia między Kuwejtem a Irakiem, dotyczący przywrócenia stosunków przyjaźni, uznania oraz związanych z tym zagadnień, podpisany w Bagdadzie w dniu 4 października 1963 r. (UNTS, t. 485, s. 327); porozumienie między rządami Pakistanu i Indii, dotyczące zaprzestania działań wojennych, podpisane w New Delhi w dniu 30 czerwca 1965 r. (UNTS, t. 550, s. 279), czy też układ współpracy w dziedzinie gospodarki rolnej między Ghaną a Izraelem, podpisany w Akrze w dniu 30 listopada 1964 r. (UNTS, t. 550, s. 345).

84 Por. porozumienie między Finlandią, Danią, Norwegią i Szwecją dotyczące współpracy technicznej krajów nordyckich z Tanganiką, podpisane w Helsinkach w dniu 15 stycznia 1963 r. (UNTS, t. 456, s. 419) oraz porozumienie między Filipinami, Malezją i Indonezją, podpisane w Manili w dniu 31 lipca 1963 r. (UNTS, t. 550, s. 345).

85 Por. niezmiennie adnotacja Sekretariatu ONZ brzmiała w takich przypadkach: „weszła w życie (data) przez podpisanie”, a jeżeli umowa miała formę wymiany not: „weszła w życie (data) przez wymianę tych not". 
wie nie były jednolite. Pierwszy sprawozdawca KPM - J. L. Brierly w projekcie przedłożonym komisji w 1950 r. uznał podpisanie jako zasadniczy sposób zawarcia umowy ${ }^{86}$. Takie rozstrzygnięcie spotkało się w wyraźnym sprzeciwem kilku członków Komisji ${ }^{87}$. W konsekwencji w tymczasowo przyjętym projekcie w $1951 \mathrm{r}$. zwyciężyła propozycja odmienna - presumpcji ratyfikacji ${ }^{88}$. Jednak H. Lauterpacht zaproponował wariantowe ujęcie tej kwestii. I tak rozwiązanie Brierly'ego uznał za wariant podstawowy - dodając $\mathrm{w}$ obu przedstawionych przez siebie sprawozdaniach (projektach) wariant odpowiedniego artykułu, w myśl którego ratyfikacja miała być tylko wówczas wymagana, gdy umowa wyraźnie ją przewiduje $e^{89}$.

Trzeci z kolei referent, G. Fitzmaurice, uznał (zgodnie ze swym dawno wyrażonym już poglądem), iż „umowy międzynarodowe [...] z zasady ogólnej ratyfikacji nie wymagają" ${ }^{\prime \prime}$.

Natomiast ostatni sprawozdawca Komisji, H. Waldock, w swym projekcie z 1962 r. zaproponował, aby do przyszłej konwencji wprowadzić dwie różne zasady:

1) wymagania ratyfikacji w stosunku do „traktatów formalnych” (formal treaties),

2) brak wymagania ratyfikacji w odniesieniu do umów $w$ formie wymiany not, wymiany listów oraz kilku innych rodzajów umów, które „mają charakter mniej formalny".

Jednak Komisja zmieniła to rozwiązanie i w projekcie przyjętym w tym samym roku ustalono ponownie ogólną zasadę domniemania na rzecz ratyfikacji, ale z zastrzeżeniem, iż umowy zawarte $\mathrm{w}$ formie uproszczonej, które zostały zdefiniowane w odrębnym artykule, stanowiły wyjątek odbiegający od tej zasadniczej reguły ${ }^{91}$.

Jest charakterystyczne, iż przedstawiciele państw wypowiedzieli się zdecydowanie przeciwko takiemu rozwiązaniu ${ }^{92}$. I ponownie stosowny przepis artykułu został zmieniony w 1965 r. zgodnie z ogólną konkluzją samej Komisji, iż „zagad-

86 Zob. art. 8 projektu „Yearbook of the ILC”, 1950, vol. II, s. 223.

87 Charakterystyczne w tym kontekście są wypowiedzi prof. R. Amado i G. Scelle’a na posiedzeniach KPM w 1950 r. (por. „Yearbook of the ILC”, 1950, vol. I, s. 66 i 73).

88 Por. dokument ONZ A/CN, 4/L, 28, w szczególności art. 4.

89 Por. dokument ONZ A/CN, 4/63 oraz A/CN, 4-87, w szczególności artykuły szóste i alternatywne ich wersje.

90 Por. dokument ONZ A/CN, 4/101, w szczególności art. 32.

91 Por. dokument ONZ A/5209 art. 121/d oraz art. 1, par. 1b.

92 Wypada wskazać, iż przeciwko zasadzie domniemania ratyfikacji wypowiedzieli się przedstawiciele rządów: Danii, Japonii, Szwecji, ZSRR i Wielkiej Brytanii (por. dokument ONZ A/6309/REV. 1, s. $120,148,182,186,192)$. Natomiast przedstawiciel rządu Izraela oświadczył, iż jest przeciwny przyjmowaniu jakiejkolwiek zasady w tym względzie. Zasadę domniemania ratyfikacji poparli przedstawiciele jedynie dwóch państw: Austrii i Jugosławii (por. odpowiednio: ibidem, s. 141 oraz s. 115 i 192). 
nienie, czy podpisanie wyraża, czy też nie wyraża zgody państwa na związanie się umową lub czy umowa wymaga ratyfikacji - jest w głównej mierze kwestią zamiaru państw"'s3.

W konsekwencji KPM - w swym ostatecznym projekcie z 1966 r. - nie wprowadziła żadnej ogólnej reguły, czy to ustalającej ratyfikację, czy też podpisanie. Wspomniany projekt w swych postanowieniach - art. 10 i 11 wymieniał tylko te przypadki, w których to podpisanie (wyjątkowo parafowanie) lub ratyfikacja, zatwierdzenie albo też przyjęcie należy uznać za właściwą formę wyrażania przez państwo zgody na związanie się umową ${ }^{94}$. Analiza prac nad projektem konwencji wiedeńskiej o prawie traktatów wskazuje, iż celem tych postanowień było przede wszystkim ustalenie okoliczności pozwalających stwierdzić, jaki był faktyczny zamiar państwa w danym konkretnym przypadku - w sprawie sposobu (formy) związania się umową. Prezentowane rozstrzygnięcie miało (zgodnie z intencją H. Waldocka) efektywnie zapobiegać przypadkom, w których stosowanie jakiejkolwiek ogólnej reguły byłoby konieczne ${ }^{95}$.

Na konferencji wiedeńskiej w 1968 r. ponownie powróciła kwestia presumpcji ratyfikacji bądź jej braku. Stało się to za sprawą poprawek zgłoszonych do projektu konwencji. Wśród grupy kilku poprawek - trzy miały charakter merytoryczny. Poprawka zgłoszona przez Polskę, Czechosłowację i Szwecję zmierzała do ustalenia zasady braku wymagania ratyfikacji. Natomiast dwie pozostałe poprawki zgłoszone przez grupę dziewięciu państw latynoamerykańskich ${ }^{96}$ oraz przez Szwajcarięę7 - proponowały zasadę odmienną - presumpcji ratyfikacji. W rezultacie żadna $\mathrm{z}$ tych poprawek nie zdołała uzyskać akceptacji większości Komisji ${ }^{98}$. Stąd w tekście konwencji wiedeńskiej z 1969 r. powrócono tylko z nieznacznymi modyfikacjami do poprzedniego brzmienia tych postanowień, zaproponowanych przez komisję

Szczegółowa analiza prac kodyfikacyjnych - daje asumpt do stwierdzenia, iż nie jest wynikiem przesłanek merytorycznych fakt, że w konwencji nie ustalono ogólnej zasady rozstrzygającej o nabraniu mocy obowiązującej przez umowę, która sama kwestii swego uprawomocnienia nie reguluje. Stało się to przede wszystkim tylko dlatego, iż żadna $\mathrm{z}$ reguł (presumpcji ratyfikacji lub jej braku) nie mogła uzyskać wymaganej większości. Jednak praktyka państw prowadzi

93 Por. Report of the ILC, 1965, s. 5.

94 Por. ibidem, s. 11-12.

95 Ibidem.

96 Por. dokumenty: ONZ A/CONF, 39/C, 1/L.38 i Add. 1 i 2 oraz ONZ A/CONF 39/C, IL. 105.

97 Por. dokument ONZ A/CONF, 39, IL. 87.

98 Jest faktem, że Polska, Czechosłowacja i Szwecja wycofały swoją poprawkę z uwagi na wynik głosowania nad poprawką o treści przeciwnej. Głosowanie to ujawniło, iż większość państw nie jest za przyjęciem zasady wymagania ratyfikacji (UN Conference, 1968, s. 94-95).

99 Wspomnianą zmianę wniosło wprowadzenie art. 13 do tekstu projektu konwencji, dotyczącego zgody na związanie się umową, którą wyraża wymiana dokumentów tworzących umowę. 
wyraźnie do wniosku, że we współczesnym prawie międzynarodowym ukształtowała się już norma zwyczajowa - treść, która pozwala uznać umowę za zawartą $\mathrm{w}$ takim przypadku w postępowaniu jednostopniowym, a więc bez potrzeby ratyfikacji - jednak z zastrzeżeniem, że państwa nie wyrażą innego zamiaru.

\section{Brak obowiązku ratyfikacji (odmowa ratyfikacji)}

Swoboda decyzji państwa w sprawie ostatecznego wyrażenia zgody na związanie się umową, która wymaga ratyfikacji jest regułą obowiązującą ${ }^{100}$. Znajduje ona wyraźne potwierdzenie nie tylko w nauce prawa międzynarodowego, ale przede wszystkim - co ważniejsze - w praktyce traktatowej państw. Wspomnianą zasadę sankcjonuje prawo zwyczajowe. Jednak tylko w sposób pośredni potwierdza ją konwencja wiedeńska o prawie traktatów ${ }^{101}$. Wypada dodać, że zarówno traktatowe, jak i zwyczajowe prawo międzynarodowe nie zna normy, która nakładałaby na państwo (na jego kompetentne organy) obowiązek wyrażenia definitywnej zgody na związanie się umową, przewidującą ratyfikację jako warunek swego uprawomocnienia się i była uprzednio w imieniu państwa podpisana. Jest znamienne, że prawo międzynarodowe zabezpiecza w ten sposób zasadę suwerenności państw, a wspomniana reguła ściśle się z nią wiąże. W konsekwencji normy prawa międzynarodowego wyraźnie limitują jedynie sposoby wyrażenia woli i deklarowania tej woli przez państwo na zewnątrz. Pozostawiają więc swobodę podjęcia ostatecznej decyzji w sprawie ratyfikacji umowy organom uprawnionym państwa.

Zatem z faktu podpisania przez przedstawiciela państwa traktatu, który przewiduje ratyfikację, wcale nie wynika obowiązek podjęcia przez państwo decyzji o dokonaniu ratyfikacji. Jak to określił J. Basdevant „ratyfikacja traktatów jest aktem nieskrępowanym, wolnym od wszelkich nakazów"102.

Współcześnie z charakteru prawnego ratyfikacji wynika jednoznacznie, że państwo może w zależności od swego uznania dokonać ratyfikacji bądź też nie ratyfikować traktatu uprzednio podpisanego w jego imieniu. Jest to, jak stwierdzał J. Makowski, „wyłączna i zarazem dyskrecjonalna prerogatywa, którą prawo

100 Stanowi ona jedną z zasad współczesnych stosunków traktatowych i odnosi się do ratyfikacji. Gdyby państwa takiej możliwości nie miały - ratyfikacja traktatu pozbawiona byłaby wszelkich racjonalnych podstaw.

101 Sankcjonuje ją „implicite” konwencja wiedeńska o prawie traktatów, bowiem nie zawiera normy, która nakładałaby na państwa obowiązek ratyfikacji umowy uprzednio podpisanej przez przedstawiciela państwa lub odmowę ratyfikacji uznawała za akt nielegalny, por. S. E. Nahlik, Konwencja wiedeńska o prawie umów międzynarodowych (przekład i przypisy), Warszawa 1971 oraz idem, Kodeks prawa traktatów, Warszawa 1976, s. 135-136.

102 Por. J. Basdevant, La conclusion et la redaction des traités et des documents diplomatique autre que les traités, RCAID 1926, t. 5, s. 587-590. 
międzynarodowe pozostawia do wyłącznej kompetencji państw"103. Takie stanowisko, powszechnie prezentowane $\mathrm{w}$ literaturze przedmiotu (i uzasadnione praktyką państw), jest nie tylko konsekwencją ewolucji poglądów w nauce prawa, ale też rezultatem zmian w sferze prawa międzynarodowego, które zaznaczyły się pod wpływem czynników zewnętrznych dla tego prawa ${ }^{104}$.

Wiązały się one ściśle z:

- powstaniem nowoczesnego państwa ze złożonym aparatem władzy (legislatywa i egzekutywa), opartym na zasadzie podziału władz,

- udziałem parlamentu w procesie zawierania umów i zmianą charakteru prawnego instytucji ratyfikacji (odrzuceniem grocjuszowskiej koncepcji mandatu),

- powstaniem zwyczajowej normy prawa międzynarodowego, której treść ustala brak obowiązku ratyfikacji umowy, w rezultacie pozwala uznać odmowę ratyfikacji umowy za akt dopuszczalny w sferze tego prawa.

Podpisanie traktatu, który przewiduje ratyfikację nie ogranicza zgodnie $\mathrm{z}$ od dawna ustaloną normą (XIX w.) swobody państwa, co do ostatecznego zaciągnięcia zobowiązań umownych ${ }^{105}$. Dotyczy to również tych przypadków, kiedy traktat zawiera postanowienia odmienne od tradycyjnych, czy standardowych lub, co czasami się zdarza, gdy pełnomocnicy przyjmą dodatkowe uzgodnienia $\mathrm{w}$ tej mierze ${ }^{106}$. I tak, umawiające się państwa mogą np. umieścić wyraźne regulacje, z których wynika, że ratyfikacja traktatu ma nastąpić $\mathrm{w}$ określonym terminie lub $\mathrm{w}$ najkrótszym możliwie czasie. Poza tym takie „przyrzeczenie ratyfikacji” może być uczynione w dodatkowych uzgodnieniach bądź wynikać $\mathrm{z}$ treści pełnomocnictw negocjatorów. Również w tych przypadkach państwa nie mają prawnego obowiązku ratyfikacji uprzednio podpisanej umowy ${ }^{107}$. Tego rodzaju stypulacje lub uzgodnienia nakładają na państwo jedynie obowiązek wszczęcia procedury ratyfikacyjnej - przedłożenia umowy kompetentnej władzy. Jest zrozumiałe, że skutków tej czynności nie zawsze można z góry przewidzieć - tym bardziej, że uczestniczy w nich parlament. Skoro konstytucyjnie upoważnionym organom państwa - prawo międzynarodowe pozostawia swobodę decyzji w sprawie wyrażenia ostatecznej zgody na związanie się umową - jest to ich wyłączna kompetencja, to należy liczyć się z potencjalną możliwością odmowy lub braku ratyfikacji umowy uprzednio podpisanej w imieniu państwa. Ponad-

103 Por. J. Makowski, Organa państwa..., s. 173 i nast.

104 Były to przemiany ustrojowe, które dokonały się pod koniec XVIII i w XIX w. Zapoczątkowały je powstanie Stanów Zjednoczonych i rewolucja francuska, por. Ch. Rousseau, op. cit., s. 200.

105 Por. ibidem, s. 200 i nast. oraz F. Dehousse, La Ratification des Traités Internationaux, Paris 1953, s. 113 i nast.

106 Przykładowo, mogą to uczynić w protokole podpisania.

107 Por. komentarz do art. 8 projektu konwencji dotyczacej prawa traktatów, opracowanego przez Ośrodek Uniwersytetu Harvarda w 1935 r. (Draft Convention on the Law of Treaties) - AJIL 1935, vol. 29, s. 769 i nast. 
to traktat może przewidywać lub może to wynikać z dodatkowych ustaleń, że będzie tymczasowo stosowany w całości lub w części. I w takim wypadku (choć postanowienia umowy wiążą sygnatariuszy umowy przed ostatecznym wyrażeniem zgody na związanie się umową - to jednak państwo nie ma obowiązku dokonania ratyfikacji umowy. Zatem można stwierdzić, że organy konstytucyjnie upoważnione do ratyfikacji umów międzynarodowych mogą nie dokonać ratyfikacji $z$ różnych przyczyn. $W$ efekcie, podpisana umowa nie wiąże. Brak ratyfikacji oznacza, że państwo nie może lub nie zamierza $z$ różnych powodów związać się daną umową w określonym momencie. $Z$ drugiej strony - nie wyklucza to wcale (np. po ustaniu przyczyny) możliwości zaciągnięcia zobowiązań wynikających z umowy.

Kontekst prawny braku ratyfikacji (odmowy ratyfikacji) umowy międzynarodowej nie oznacza braku implikacji politycznych z tym związanych. Skutki polityczne mogą i są najrozmaitsze i trudno poddają się przejrzystej klasyfikacji. Warto jednak wskazać, iż w tym drugim ujęciu brak ratyfikacji (odmowa ratyfikacji) umowy międzynarodowej może być uznana „za akt mało przyjazny”, czy „niewłaściwy”, a nawet „czyniący szkodę dobremu imieniu państwa” ${ }^{108}$. W rezultacie brak ratyfikacji (odmowa ratyfikacji) może naruszać przyjazne stosunki wcześniej występujące między umawiającymi się stronami - to jednak na płaszczyźnie prawnomiędzynarodowej - jest zachowaniem (działaniem) legalnym ${ }^{109}$. Sama umowa w swych stypulacjach zastrzega bowiem, iż dojdzie do skutku pod warunkiem dokonania jej ratyfikacji przez umawiające się państwa. Jest oczywiste, iż innej ocenie pozaprawnej podlega brak ratyfikacji umowy w uzasadnionych sytuacjach, np. kiedy parlament nie wyraża zgody na związanie się daną umową lub umowa nie uzyskuje wymaganej aprobaty przed ratyfikacją $\mathrm{w}$ drodze referendum.

W nauce prawa międzynarodowego pojawił się najpierw pogląd uzasadniający odmowę ratyfikacji traktatu, związany z przekroczeniem pełnomocnictw. Wiązało się to ściśle z zachowaniem negocjatorów i sposobem wypełnienia przez nich instrukcji negocjacyjnych. W sytuacji, kiedy pełnomocnik przekroczył swoje uprawnienia. lekceważąc tym samym instrukcje dane mu przez „głowę państwa", to panujący nabywał bezsporne prawo do odmowy i odrzucenia podpisanego przez swego pełnomocnika traktatu ${ }^{110}$. Takie stanowisko, co podkreślano

108 Por. ibidem.

109 Por. ibidem.

110 W ten sposób ratyfikacja stanowiła formę kontroli (swoistego radzaju „klapę bezpieczeństwa”) panującego nad działaniami negocjatorów, których zakres działania wyznaczały przekazane im instrukcje negocjacyjne. Jeśli traktat był zawarty z przekroczeniem takich pełnomocnictw, to władca uzyskiwał prawo do odmowy ratyfikacji. Tak więc obowiązująca w tym czasie reguła obowiązku ratyfikacji odnosiła się wyłącznie do traktatów podpisanych przez negocjatorów zgodnie z zakresem ich pełnomocnictw. Dlatego też M. de Wicquefort pisał, iż „jeśli ambasador nie przekroczył 
już wcześniej, było odbiciem powszechnie akceptowanej w okresie absolutyzmu - teorii mandatu. Wspomniana konstrukcja prawna warunkowała jednoznacznie skutki działań pełnomocnika. Skoro negocjator - w myśl wywodzącej się z prawa rzymskiego (rozwiniętej w prawie kanonicznym) - zasady „qui facit per alium, facit per se" - swoim podpisem zobowiązywał mocodawcę (jednostkowego suwerena) w sposób ostateczny, z tym wszakże oczywistym zastrzeżeniem, że działał stosownie do instrukcji wynikających z zakresu przyznanych mu pełnomocnictw ${ }^{111}$. $Z$ tych względów akt ratyfikacji miał w istocie charakter formalny, gdyż panujący $\mathrm{w}$ istocie - ratyfikując podpisaną przez swego pełnomocnika umowę - potwierdzał w zasadzie wystawione uprzednio pełnomocnictwa. Stąd w okresie absolutyzmu - wyznaczającym obowiązek ratyfikacji traktatu uprzednio podpisanego przez pełnomocnika - występowała tylko wyjątkowa możliwość odmowy ratyfikacji. Była ona jednoznacznie ograniczona do przypadków przekroczenia pełnomocnictw.

Wraz ze zmianą charakteru państwa (i w rezultacie zmian w sferze prawa międzynarodowego) oraz odrzuceniem grocjuszowskiej koncepcji mandatu - akt ratyfikacji zyskuje konstytutywny charakter. W konsekwencji stopniowo zaczyna kształtować się odmienna reguła - braku obowiązku ratyfikacji ${ }^{112}$. Znajduje ona swoje odzwierciedlenie nie tylko w poglądach doktryny, ale przede wszystkim i co najważniejsze w obrocie traktatowym państw. Warto podkreślić, że znika stopniowo przyrzeczenie ratyfikacji występujące zarówno w tekstach pełnomocnictw, jak i w postanowieniach samych traktatów. Również katalog przyczyn uzasadniających odmowę ratyfikacji umowy ulega znacznemu rozszerzeniu $^{113}$.

swego pełnomocnictwa [...] władca jest zobowiązany do przyjęcia i ratyfikowania tego, co zawarte w jego imieniu i na podstawie wystawionych przez niego pełnomocnictw" - zob. M. de Wicquefort, op. cit., s. 380.

111 Por. J. M. Jones, op. cit., s. s. 67.

112 Zasada braku obowiązku ratyfikacji umowy uprzednio podpisanej przez pełnomocnika - mimo że negocjator działał $\mathrm{w}$ granicach przyznanych mu pełnomocnictw - ukształtowała się w połowie XIX w. Praktyczne potwierdzenie tej reguły miało miejsce w $1842 \mathrm{r}$. w dokumencie podpisanym przez 5 państw (Anglię, Francję, Prusy, Rosję i Stany Zjednoczone) - głównych uczestników w tym czasie stosunków traktatowych. W tymże roku Francja odmówiła ratyfikacji układu londyńskiego podpisanego 20 grudnia 1841 r., zabraniającego handlu Murzynami. Rząd francuski powołał się przy tym na fakt, że państwa mogą w zależności od swego uznania ratyfikować lub nie podpisywane w ich imieniu traktaty. Tym samym w swoim stanowisku Francja wskazała jednoznacznie na przekonanie o braku obowiązku ratyfikacji. Teza wysunięta przez rząd francuski w tym przypadku była równoznaczna z uznaniem swobody państw w sprawie podjęcia decyzji o ratyfikacji umowy uprzednio podpisanej przez przedstawiciela państwa. Dodać wypada, iż pozostałe państwa w protokole z 9 listopada 1842 r. - aczkolwiek wyraziły swoją dezaprobatę wobec zachowania Francji, to jednak nie podważyły argumentacji tej decyzji przedstawionej przez rząd tego państwa w formie uzasadnienia, por. Ch. Rousseau, op. cit., s. 201; F. Dehousse, op. cit., s. 114; P. Vexler, De l'Obligation de ratifier les traités regulierement conclus, Paris 1921, s. 57-58.

113 Por. komentarz do art. 8 projektu konwencji o prawie traktatów, przygotowany przez Uniwersytet Harvarda w 1935 r. - AJIL 1935, vol. 29, s. 769 i nast. 
Już w wieku XIX doktryna zaczęła uznawać odmowę ratyfikacji za akt dopuszczalny w sferze prawa międzynarodowego. Nie czyniła jednak tego bez zastrzeżeń. Wskazywano bowiem, iż ze względów moralnych lub politycznych ratyfikacja umowy uprzednio podpisanej w imieniu państwa przez pełnomocnika uznana być musi za obowiązek. Stąd często zasada braku obowiązku ratyfikacji - obowiązująca w prawie międzynarodowym - ograniczana była katalogiem „poważnych przyczyn” moralnie upoważniających państwo do podjęcia decyzji o jej odmowie ${ }^{114}$. I tak, C. Calvo wskazywał, iż „nie ma wątpliwości co do tego, że prawo nieratyfikowania traktatu jest $\mathrm{w}$ równej mierze niezaprzeczalne, jak prawo do układania się i zawierania umów międzynarodowych i że istnieje ono zasadniczo nawet wówczas, gdy nie było wyraźnie i formalnie zastrzeżone", to jednak z uwagi na fakt, że „odmowa ratyfikacji zawiera zaprzeczenie danego słowa, obietnicy uczynionej przez układającego się i podobne zaprzeczenie może mieć bardzo poważne skutki dla obu układających się stron, to słuszne poszanowanie, które winny sobie nawzajem okazywać państwa wymaga, aby wykonanie tego prawa zamykało się w granicach możliwie najwęższych i kierowało się zawsze przyczynami szczególnie ważnymi”"15. Do przyczyn tego rodzaju zaliczał Calvo:

- moralną lub fizyczną niemożność wykonania warunków przyrzeczonych,

- oczywisty błąd dotyczący faktu o zasadniczym znaczeniu,

- niezamierzoną zmianę, która zdarzyła się w trakcie negocjacji lub w chwili podpisania traktatu, a sprzeciwiającą się celowi, do którego pełnomocnicy byli upoważnieni zmierzać,

- brak pełnomocnictw,

- włączenie do traktatu postanowień nieprzewidzianych lub formalnie zakazanych w instrukcjach negocjacyjnych,

- brak przyrzeczeń zasadniczych, uznanych za warunek sine qua non,

- zobowiązania sprzeczne z prawem wewnętrznym państwa ${ }^{116}$.

Jest charakterystyczne dla poglądów doktryny w tym czasie, iż zwracano uwagę na ograniczenie przypadków odmowy ratyfikacji - sygnalizując istnienie "obowiązku ratyfikacji w sensie moralnym”, a nie prawnym. Często formułowany katalog przyczyn uzasadniających odmowę ratyfikacji umowy mógł być praktycznie wykorzystany dla uzasadnienia niemal każdego przypadku jej odmowy.

Na gruncie tej teorii wielu jej zwolenników podejmowało próby klasyfikacji przyczyn, które pozwalały uznać odmowę ratyfikacji traktatu za prawnie dopusz-

114 Por. F. Dehousse, op. cit., s. 114 i nast.; L. Oppenheim, op. cit., s. $722-723$ oraz D. Anzilotti, op. cit., s. $370-371$.

115 Cytowane za opracowaniem harwardzkim - por. AJIL 1935, col. 29 Supl., s. 769-778 .

116 Ibidem. 
czalną i uzasadnioną. Przedstawiane i szeroko argumentowane przez doktrynę „przyczyny” można ująć zdaniem F. O. Wilcoxa w następujący katalog:

1) przekroczenie pełnomocnictw,

2) wspólny błąd co do faktu, którego dostrzeżenie mogłoby uniemożliwić zawarcie umowy,

3) fizyczna lub moralna niemożliwość wykonania zobowiązań ujętych w umowie,

4) użycie siły lub groźby jej użycia wobec przedstawiciela państwa,

5) zasadnicza zmiana okoliczności, która nastąpiła po podpisaniu umowy,

6) brak pełnomocnictw,

7) kiedy traktat zawiera postanowienie sprzeczne $z$ prawem wewnętrznym jednej z umawiających się stron,

8) zmiana rządu, która nastąpiła po podpisaniu traktatu,

9) kiedy umowa nie spotkała się $z$ aprobatą uprawnionego organu, który to organ posiada kompetencje do zawarcia umowy,

10) opinia publiczna jest przeciwna zawarciu umowy $y^{117}$

Jednak z czasem moralny obowiązek ratyfikacji stał się bez znaczenia, a coraz wyraźniej zyskuje potwierdzenie w doktrynie zasada braku obowiązku ratyfikacji. Stwierdza się bowiem, że normy prawa międzynarodowego nie nakładają na państwa sygnatariuszy obowiązku ratyfikacji ${ }^{118}$. Nie przedstawia się również katalogu przyczyn usprawiedliwiających odmowę ratyfikacji. Zresztą coraz częściej termin „odmowa ratyfikacji” jest zastępowany określeniem „brak obowiązku ratyfikacji” czy też „brak ratyfikacji” lub „odrzucenie ratyfikacji”. Jest też zrozumiałe, że państwo, które nie dokonało ratyfikacji, będzie uzasadniało swoje zachowanie niezwykle ważnymi powodami - w jego odczuciu - przekonująco tłumaczącymi brak ratyfikacji. Mogą one jednak nie okazać się takimi w przeświadczeniu i w ocenie pozostałych kontrahentów umowy.

Zarówno współczesna doktryna, jak i samo prawo międzynarodowe uznaje zasadę swobodnej decyzji państwa w sprawie ostatecznego wyrażenia zgody na związanie się z umową, która przewiduje ratyfikację - jako warunek swego uprawomocnienia. Jej ważne potwierdzenie ustalał już art. 7 konwencji hawańskiej

117 Por. F. O. Wilcox, The ratification of International Convention, London 1935, s. 103 i nast. Również szeroki katalog usprawiedliwionych motywów, które stanowią podstawę do podjęcia przez państwo decyzji o odmowie ratyfikacji umowy przedstawia J. Makowski. Jego zdaniem przykładowo są to: a) przekroczenie instrukcji lub pełnomocnictw, b) wady oświadczenia woli, c) mutuus dissensus (wspólny sprzeciw, wspólne odstąpienie), d) innowacja, e) ważne wydarzenie zaszłe po podpisaniu umowy (np. wojna, siła wyższa) - por. J. Makowski, Organa państwa..., s. 173-174. W doktrynie wskazuje, iż zmiana rządu może być rzeczywistą i na ogół zrozumiałą przyczyną odmowy ratyfikacji uprzednio podpisanej umowy. Interesujący w tym względzie jest przykład Francji, która odmówiła (właśnie po zmianie rządu) ratyfikacji Układu o Wspólnocie Obronnej z 1952 r.

118 Ibidem oraz por. także F. O. Wilcox, op. cit., s. 101-121. 
o traktatach (Convention on Treaties) z 20 lutego 1928 r., który przewidywał: „Odmowa ratyfikacji lub formułowanie zastrzeżeń jest przejawem suwerenności każdego państwa i jako taka stanowi realizację prawa, które nie narusza norm prawa międzynarodowego ani etyki. W przypadku odmowy należy powiadomić o tym pozostałe umawiające się strony"119. Również w raporcie specjalnego Komitetu Zgromadzenia Ligi Narodów z 1930 r. została potwierdzona swoboda decyzji państw w sprawie podpisania i ratyfikacji umów międzynarodowych oraz przystąpienia do nich ${ }^{120}$. W dokumencie tym wskazano, że odmowa ratyfikacji może być lub może nie być w zgodzie z życzeniem danego państwa. Wymagane było natomiast podanie informacji o odmowie adresowanej do Sekretarza Generalnego Ligi. Ten wymóg odnosił się do umów przygotowanych pod auspicjami tej organizacji międzynarodowej ${ }^{121}$.

W KPM ONZ podczas prac przygotowawczych nad kodyfikacją prawa traktatów zasadę braku obowiązku ratyfikacji potwierdził wyraźnie jedynie pierwszy sprawozdawca komisji, J. Brierly, w swym trzecim raporcie przedstawionym komisji w 1952 r. Wskazał on, iż zasada ta obowiązuje od czasów rewolucji francuskiej i amerykańskiej, a wspomnianą zasadę braku obowiązku ratyfikacji ujął w art. 7 projektu ${ }^{122}$.

Kolejni trzej referenci KPM nie podejmowali w swych sprawozdaniach tej problematyki - uznając ją za oczywistą i niebudzącą żadnych większych kontrowersji. Podobnie rzecz się miała podczas prac na konferencji wiedeńskiej, zamykających etap kodyfikacji prawa traktatów. W rezultacie konwencja wiedeńska „milcząco” sankcjonuje zasadę braku obowiązku ratyfikacji, bowiem nie zna normy, która wprowadzałaby taki obowiązek lub wspomnianą zasadę braku obowiązku ratyfikacji ograniczała w jakikolwiek sposób. Należy podkreślić, że państwa zachowują pełną swobodę decyzji w przedmiocie ratyfikacji umowy $\mathrm{z}$ uwagi na fakt, że normy prawa międzynarodowego nie nakładają na nie takiego obowiązku. Podkreślał to szczególnie J. L. Brierly, który dowodził, iż „nie jest prawnym ani moralnym obowiązkiem państwa ratyfikowanie umowy podpisanej przez jego własnych pełnomocników, można tylko zaznaczyć, że odmowa ra-

119 Por. AJIL, 1935, v. 29 Supl., s. 769-775.

120 Ibidem.

121 Por. F. O Wilcox, op. cit., s. 117-119. Autor podaje dane przedstawione przez Sekretarza Generalnego Ligi Narodów w 1931 r. o zamiarach państw, które podpisały konwencje przygotowane pod auspicjami tej organizacji w latach 1921-1929, a nie dokonały ich ratyfikacji. W sumie wysłano 261 listów z zapytaniem o ratyfikację podpisanych konwencji. Nie udzielono odpowiedzi w 99 przypadkach. Tylko w 6 przypadkach wskazano, że w najbliższym czasie zostanie złożony dokument ratyfikacyjny. Ani jedno państwo nie poinformowało, że nie zamierza się związać daną umową. Najczęściej twierdzono, że postępowanie ratyfikacyjne w sprawie podpisanych konwencji jest w toku.

122 Art. 7 projektu przedstawiony przez J. Brierly'ego przewidywał: „If a treaty is subject to ratification, signature by a State does not create for that State any obligation to ratify the treaty". Uzasadnienie tej reguły zawarł Brierly w komentarzu do tego artykułu, odsyłając po szczegóły do opracowania harwardzkiego - „Yearbook of the ILC” 1952, vol. II (Doc. A/CN. 4/54), s. 54. 
tyfikacji jest poważną decyzją, która nie powinna być podejmowana lekkomyślnie"123. Warto zaznaczyć, iż podobny pogląd sformułował już wcześniej sędzia J. B. Moore w swym votum seperatum do orzeczenia z 30 sierpnia 1924 r. Stałego Trybunału Sprawiedliwości Międzynarodowej w sprawie Mavrommatisa wskazując, iż „doktryna, która zobowiązywała państwa do ratyfikacji wszystkiego, co negocjatorzy działający w granicach przyznanych im pełnomocnictw mogli podpisać i dlatego umowy te mogły być uznane za prawnie obowiązujące przed ich ratyfikowaniem, została odrzucona i pozostaje - jako echo przeszłości"124.

Praktyka wskazuje, iż odmowa ratyfikacji traktatu winna być nie tylko zakomunikowana, ale i uzasadniona przez państwo podejmujące taką decyzję. Choć normy prawa międzynarodowego nie nakładają na państwa takich obowiązków, to jednak w praktyce państwa „czują się jednak zobowiązane” do przedstawienia przyczyn (lub motywów) takiej decyzji (braku ratyfikacji lub jej odmowy). Wspomniane zachowanie dowodzi nie tyle, że państwa czują się moralnie zobowiązane do uzasadnienia takiej decyzji, ale że takie działanie może w pewnym stopniu łagodzić skutki (implikacje polityczne) związane z brakiem ratyfikacji (zwłaszcza jej odmową).

Brak obowiązku ratyfikacji w pełni potwierdza polska doktryna prawa: „Zgodnie z prawem międzynarodowym państwo może odmówić ratyfikacji” pisze K. Skubiszewski ${ }^{125}$. Jego zdaniem "gdyby państwa nie miały takiego prawa do odmowy, ratyfikacja traktatu stałaby się formalnością pozbawioną większego znaczenia" ${ }^{26}$. Podobne stanowisko prezentuje J. Makowski, K. Libera, L. Gelberg czy M. Frankowska ${ }^{127}$.

Również prawo wewnętrzne zdecydowanie potwierdza zasadę braku obowiązku ratyfikacji. Jak stwierdził to jeszcze F. Dehousse „nigdy podejmowanie czynności ratyfikacyjnych nie jest narzucone kompetentnemu organowi państwa”, a nawet jego zdaniem „aprobata parlamentu nie stanowi bezwzględnego obowiązku prawnego do podjęcia decyzji o ratyfikacji i wymianie lub złożeniu dokumentu ratyfikacyjnego ${ }^{128}$. Teza Dehousse'a zachowuje w pełni swoją aktualność. Brak presumpcji ratyfikacji i obowiązku ratyfikacji stanowi swoiste signum temporis zmiany charakteru prawnego instytucji ratyfikacji umów międzynarodowych w dobie współczesnej.

123 Por. J. Brierly, The Law of Nations, London 1928, s. 166.

124 Zob. Publications of PCIJ, Series A, Nr 2, s. 57.

125 Por. K. Skubiszewski, Zachodnia granica Polski w świetle traktatów, Poznań 1975, s. 67.

126 Ibidem.

127 Por. J. Makowski, Organa państwa..., s. 157-161, L. Gelberg, Z problematyki umów międzynarodowych, [w:] Księga ku czci Juliana Makowskiego, Warszawa 1957, s. 132 i nast. oraz M. Frankowska, Umowy międzynarodowe $w$ formie uproszczonej..., s. 63-74.

128 Por. F. Dehousse, op. cit., s. 114 i nast. 


\section{Bibliografia}

Anzilotti D., Cours de Droit International, Paris 1929.

Basdevant J., La conclusion et la redaction des traités et des documents diplomatique autre que les traités, „Recueil des Cours de l'Académie de Droit International de la Haye" 1926, t. 5.

Berber F., Lehrbuch des Völkerrecht, t. I, München 1960.

Bierzanek R., Jakubowski J., Symonides J., Prawo międzynarodowe i stosunki międzynarodowe, Warszawa 1980.

Bittner L., Die Lehre von den vőlkerrechtlichen Vetragsurkunden, Berlin - Leipzig 1924.

Blix H., The Requirement of Ratification, „British Yearbook of International Law” 1953, vol. 30 .

Blix H., Treaty - Making Power, London 1960.

Brierly J. L., Law of Nation, Oxford 1936.

Bynkershoek van K., Quaestionum Juris Publici Libri Duo, Leyda 1737, ks. II, rozdz. VII.

Calvo Ch., Le droit international, vol. III, Paris - Berlin 1888.

Dehousse F., La coclusion des traites d'apres la pratique constitutionnelle et diplomatique belge, „Annales de l'Institut de droit compare de l'Universite de Paris” 1938, t. III.

Dehousse F., La Ratification des Traités Internationaux, Paris 1935.

Draft Convention on the Law of Treaties, "American Journal of International Law” 1935, vol. 29, Supplement.

Fauchille P., Traite de droit international public, t. I, Paris 1926.

Frankowska M., De la pretundue prosomption en faveur de la ratification des traités, RGDIP, 1969, nr 73.

Frankowska M., O domniemaniu wymagania ratyfikacji umów międzynarodowych, „Państwo i Prawo" 1969, nr 3.

Frankowska M., Umowa międzynarodowa w formie uproszczonej, Warszawa 1981.

Frankowska M., Umowa międzynarodowa. Wprowadzenie do prawa traktatów, Warszawa 1977.

Freymond P., La Ratification des Traités et le Problème des Rapports entre le Droit International et le Droit Interne, Paris - Lausanne 1947.

Gelberg L., Z problematyki umów międzynarodowych, [w:] Księga ku czci Juliana Makowskiego, Warszawa 1957.

Gentilis A., De iure belli libri tres (1958), wyd. Classics of International Law. Oxford London 1933, ks. III, rozdz. 14.

Gwiżdż A., Kontrola parlamentarna polityki zagranicznej, cz. I, „Sprawy Międzynarodowe" 1967, nr 6. 
Holloway K., Modern Trends in Treaty Law, London 1967.

International Court of Justice, Reports of Judgements, „Advisory Opinions and Orders” 1965, 1969.

Jones J. M., Full powers and ratification, Cambridge 1946.

Lapidoth R., La coclusion des traitès internationaux en Israel, Paris 1962.

Laws and Practices concerning the Conclusion of Treaties, United Nations Legislative Series, New York 1953.

Makowski J., Charakter prawny umów zawartych podczas II wojny światowej, „Państwo i Prawo" 1948, nr 5/6.

Makowski J., O zawieraniu umów międzynarodowych, Warszawa 1937.

Makowski J., Organa państwa $w$ stosunkach międzynarodowych. Zjazdy i konferencje międzynarodowe. Umowa międzynarodowa, Warszawa 1957.

Makowski J., Podręcznik Prawa Międzynarodowego, Warszawa 1948.

McClure W. M., International Executive Agreements, New York 1941.

McNair A. D., The Law of Treaties, Oxford 1961.

Mirkine-Guetzevitch B., Droit constitutionnel international, Paris 1933.

Moore J. B., Digest of International Law, Washington 1906.

Nahlik S. E., Kodeks prawa traktatów, Warszawa 1976.

Nahlik S. E., Konwencja wiedeńska o prawie umów międzynarodowych (przekład i przypisy), Warszawa 1971.

Nalik S. E., O wejściu w życie umowy międzynarodowej, „Zeszyty Naukowe Uniwersytetu im. M. Kopernika w Toruniu, Prawo II" 1965, z. 5.

Nalik S. E., Wstęp do nauki prawa międzynarodowego, Warszawa 1967.

Oppenheim L., International Law, wyd. VIII - H. Lauterpachta, t. I, London 1955.

Polenc O. E., Ratyfikacija Mieżdunarodnych Dogoworow, Moskwa 1950.

Publications of Permanent Court of International Justice, Series A, Nr 2.

Rivier A., Pricipes du droit des gens, t. II, Paris 1869.

Rousseau Ch., Principes generaux de droit international public, t. I, Paris 1944.

Skubiszewski K., Zachodnia granica Polski w świetle traktatów, Poznań 1975.

Słowiński F., Prawo narodów naturalne połaczone z praktyka państw europejskich, Kraków 1822.

Tałałajew A. N., Prawo mieżdunarodnych dogoworow, Moskwa 1980.

United Nations Conference on the Law of Treaties, First Session 1968, Second Session 1969. Official Records.

United Nations Treaty Series T. 456, 485, 550.

Vattel de E., Prawo narodów, przekł. B. Winiarski wg wyd. z 1758), t. I, Warszawa 1985.

Vexler P., De l'Obligation de ratifier les traités regulierement conclus, Paris 1921.

Visscher de P., De la conclusion des traités internationaux, Bruxelles 1943. 
Wicquefort de M., L’Ambassadeur et ses fonctions, t. II, Haga 1724.

Wilcox F. O., The Ratification of International Conventions, London 1935.

Wolf Ch., Ius gentium methodo scientifica pertractatum (1764), wyd. Classics of International Law, Oxford - London 1943.

Wyrozumska A., Umowa międzynarodowa. Teoria i praktyka, Warszawa 2006.

„Yearbook of International Law Commission” 1953, vol. II; 1954, vol. II; 1956, vol. II; 1957, vol. II; 1958, vol. II; 1959, vol. II; 1962, vol. II; 1963, vol. II; 1964, vol. II; 1965 , vol. II. 